\title{
Aerosol-radiation feedback deteriorates the wintertime haze in the North China Plain
}

\author{
Jiarui Wu ${ }^{1,7}$, Naifang Bei ${ }^{2}$, Bo Hu ${ }^{3}$, Suixin Liu ${ }^{1}$, Meng Zhou ${ }^{4}$, Qiyuan Wang ${ }^{1}$, Xia Li ${ }^{1,6}$, Lang Liu ${ }^{1}$, Tian Feng ${ }^{1}$, \\ Zirui Liu ${ }^{3}$, Yichen Wang ${ }^{1}$, Junji Cao ${ }^{1,4}$, Xuexi Tie ${ }^{1}$, Jun Wang ${ }^{5}$, Luisa T. Molina ${ }^{6}$, and Guohui Li ${ }^{1,4}$ \\ ${ }^{1}$ Key Lab of Aerosol Chemistry and Physics, SKLLQG, Institute of Earth Environment, Chinese Academy of Sciences, \\ Xi'an, Shaanxi, 710061, China \\ ${ }^{2}$ School of Human Settlements and Civil Engineering, Xi'an Jiaotong University, Xi'an, Shaanxi, 710049, China \\ ${ }^{3}$ State Key Laboratory of Atmospheric Boundary Layer Physics and Atmospheric Chemistry, Institute of Atmospheric \\ Physics, Chinese Academy of Sciences, Beijing, 100029, China \\ ${ }^{4}$ CAS Center for Excellence in Quaternary Science and Global Change, Xi' an, Shaanxi, 710061, China \\ ${ }^{5}$ Department of Chemical and Biochemical Engineering \& Interdisciplinary Graduate Program in Geo-Informatics, \\ University of Iowa, Iowa City, IA 52242, USA \\ ${ }^{6}$ Molina Center for Energy and the Environment, La Jolla, CA 92037, USA \\ ${ }^{7}$ University of Chinese Academy of Science, Beijing, 100049, China
}

Correspondence: Guohui Li (ligh@ieecas.cn)

Received: 12 December 2018 - Discussion started: 29 January 2019

Revised: 19 June 2019 - Accepted: 25 June 2019 - Published: 10 July 2019

\begin{abstract}
Atmospheric aerosols scatter or absorb a fraction of the incoming solar radiation to cool or warm the atmosphere, decreasing surface temperature and altering atmospheric stability to further affect the dispersion of air pollutants in the planetary boundary layer (PBL). In the present study, simulations during a persistent and heavy haze pollution episode from 5 December 2015 to 4 January 2016 in the North China Plain (NCP) were performed using the Weather Research and Forecasting model with Chemistry (WRF-Chem) to comprehensively quantify contributions of aerosol shortwave radiative feedback (ARF) to near-surface (around $15 \mathrm{~m}$ above the ground surface) $\mathrm{PM}_{2.5}$ mass concentrations. The WRF-Chem model generally performs well in simulating the temporal variations and spatial distributions of air pollutants concentrations compared to observations at ambient monitoring sites in the NCP, and the simulated diurnal variations of aerosol species are also consistent with the measurements in Beijing. Additionally, the model simulates the aerosol radiative properties, the downward shortwave flux, and the PBL height against observations in the NCP well. During the episode, ARF deteriorates the haze pollution, increasing the near-surface $\mathrm{PM}_{2.5}$ concentrations in the NCP by $10.2 \mu \mathrm{g} \mathrm{m}^{-3}$ or with a contribution of $7.8 \%$
\end{abstract}

on average. Sensitivity studies have revealed that high loadings of $\mathrm{PM}_{2.5}$ attenuate the incoming solar radiation reaching the surface to cool the low-level atmosphere, suppressing the development of the PBL, decreasing the surface wind speed, further hindering the $\mathrm{PM}_{2.5}$ dispersion, and consequently exacerbating the haze pollution in the NCP. Furthermore, when the near-surface $\mathrm{PM}_{2.5}$ mass concentration increases from around 50 to several hundred $\mu \mathrm{g} \mathrm{m}^{-3}$, ARF contributes to the near-surface $\mathrm{PM}_{2.5}$ by more than $20 \%$ during daytime in the NCP, substantially aggravating the heavy haze formation. However, when the near-surface $\mathrm{PM}_{2.5}$ concentration is less than around $50 \mathrm{\mu g} \mathrm{m}^{-3}$, ARF generally reduces the nearsurface $\mathrm{PM}_{2.5}$ concentration due to the consequent perturbation of atmospheric dynamic fields.

\section{Introduction}

Atmospheric aerosols, produced both naturally and anthropogenically, influence the radiative energy budget of the Earth's atmospheric system in many ways. They scatter or absorb a fraction of the incoming solar radiation to cool or warm the atmosphere, decreasing surface temperature and 
altering atmospheric stability (e.g., Ackerman, 1977; Jacobson, 1998, 2002). Also, they serve as cloud condensation nuclei (CCN) and ice nuclei (IN), thus modifying cloud optical properties and lifetime (e.g., Zhang et al., 2007; Li et al., 2008a, b, 2009). Among those impacts, the scattering and absorption of solar radiation by aerosols and the associated feedbacks (hereafter referred to as aerosol-radiation feedback or ARF) not only constitute one of the main uncertainties in climate prediction (IPCC, 2007), but also substantially affect the atmospheric chemistry by perturbing the temperature profile and moisture, winds, and planetary boundary layer (PBL) stability (Boucher et al., 2013). In particular, as a short-lived pollutant with uneven distribution and physical and chemical heterogeneities in the atmosphere, ARF varies by more than a factor of 10 with location or time of emissions (Penner et al., 2010).

During wildfire with high-loading absorbing aerosols, ARF has been reported to heat the atmosphere and cool the surface, and thence enhance the PBL stability (e.g., Grell et al., 2011; Fu et al., 2012; Wong et al., 2012). In addition, numerous studies have been performed to evaluate impacts of ARF of dust on the regional meteorology and climate (e.g., Perez et al., 2006; D. F. Zhang et al., 2009; Santese et al., 2010). Anthropogenic aerosols, dominated by scattering components, such as organics and sulfate, primarily attenuate the incoming solar radiation down to the surface, cooling the temperature of the low-level atmosphere to suppress the development of the PBL and hinder the aerosol dispersion in the vertical direction (e.g., Fast et al., 2006; Vogel et al., 2009; Zhang et al., 2010). In addition, the temperature profile perturbation caused by ARF also alters cloud formation and development, possibly causing the precipitation delay or decrease (e.g., Zhao et al., 2005; Koch and Del Genio, 2010; Ding et al., 2013).

Rapid industrialization and urbanization in China have significantly elevated the concentrations of aerosols or fine particulate matter $\left(\mathrm{PM}_{2.5}\right)$, causing frequent occurrence of haze pollution, particularly during wintertime in North China (e.g., Zhang et al., 2013; Pui et al., 2014). Guo et al. (2014) have elucidated the haze formation mechanism in China, highlighting the efficient aerosol nucleation and growth during haze episodes. Moreover, high-loading aerosols during heavy haze episodes induce efficient ARF, encumbering the PBL development and further deteriorating the haze pollution. It is worth noting that ARF increases precursors for the aerosol nucleation and growth in the PBL, such as sulfuric and organic gases, causing efficient aerosol nucleation and growth (Zhang et al., 2004; Guo et al., 2014). Based on field measurements, recent studies have proposed that the high level of $\mathrm{PM}_{2.5}$ increases the stability of PBL due to ARF and further decreases the PBL height (PBLH), consequently enhancing $\mathrm{PM}_{2.5}$ concentrations ([ $\left.\mathrm{PM}_{2.5}\right]$ ) (Quan et al., 2013; Petäjä et al., 2016; Yang et al., 2016; Tie et al., 2017; Ding et al., 2017). Online-coupled meteorology and chemistry models have also been used to verify the impact of ARF on the
PBLH and near-surface $\left[\mathrm{PM}_{2.5}\right]$ during haze episodes in $\mathrm{Eu}-$ rope, eastern China, and northern China (Forkel et al., 2012; Z. F. Wang et al., 2014; Wang et al., 2015; Zhang et al., 2015; Gao et al., 2015). However, the ARF impact on nearsurface $\left[\mathrm{PM}_{2.5}\right]$ varies, depending on the evaluation time and location (Table 1). For example, the two-way coupled WRF-CMAQ (Community Multiscale Air Quality) system has been employed to evaluate the ARF contribution to the haze formation in January 2013 over the North China Plain (NCP), showing that ARF reduces the PBLH by $100 \mathrm{~m}$ and enhances near-surface $\left[\mathrm{PM}_{2.5}\right]$ by up to $140 \mu \mathrm{g} \mathrm{m}^{-3}$ in Beijing (J. Wang et al., 2014). Therefore, it is still imperative to comprehensively quantify the ARF contribution to nearsurface $\left[\mathrm{PM}_{2.5}\right]$ under various pollution levels to provide the underlying basis for supporting the design and implementation of emission control strategies.

In this study, simulations are performed using the Weather Research and Forecasting model with Chemistry (WRFChem) to interpret the relationship between the near-surface $\left[\mathrm{PM}_{2.5}\right]$ and the PBLH and further quantify the ARF contribution to near-surface $\left[\mathrm{PM}_{2.5}\right]$ under various pollution levels. The model and methodology are described in Sect. 2. Analysis results and discussions are presented in Sect. 3, and summary and conclusions are given in Sect. 4.

\section{Model and methodology}

\subsection{WRF-Chem model and configurations}

The WRF-Chem model (Grell et al., 2005) with modifications by Li et al. (2010, 2011a, b, 2012) is applied to evaluate effects of ARF on the wintertime haze formation in the NCP. The model includes a new flexible gas-phase chemical module, which can be used with different chemical mechanisms, such as the Carbon Bond Mechanism (CBIV), Regional Acid Deposition Mechanism 2 (RADM2), and Statewide Air Pollution Research Center mechanism (SAPRC). In the study, the SAPRC99 chemical mechanism is used based on the available emission inventory. For the aerosol simulations, the CMAQ/models3 aerosol module (AERO5) developed by the US EPA has been incorporated into the model (Binkowski and Roselle, 2003). The wet deposition is based on the method in the CMAQ module, and the dry deposition of chemical species follows Wesely (1989). The photolysis rates are calculated using the FTUV (fast radiation transfer model) with the aerosol and cloud effects on photolysis ( $\mathrm{Li}$ et al., 2005, 2011a).

It is worth noting that the most recent extension of ISORROPIA, known as ISORROPIA II, has incorporated a larger number aerosol species (Ca, Mn, $\mathrm{K}$ salts) and is designed to be a superset of ISORROPIA (Fountoukis et al., 2009). However, the ISORROPIA version II uses the exact same routines as ISORROPIA to compute the equilibrium composition, which produces identical results to ISORROPIA when 
Table 1. Impact of ARF on near-surface $\left[\mathrm{PM}_{2.5}\right]$ in China.

\begin{tabular}{|c|c|c|c|}
\hline Reference & Time & Location & Impact on $\left[\mathrm{PM}_{2.5}\right]$ \\
\hline $\begin{array}{l}\text { Z. F. Wang et al. } \\
(2014)\end{array}$ & January 2013 & Beijing-Tianjin-Hebei & $+10 \%-30 \%$ \\
\hline J. Wang et al. (2014) & January 2013 & North China Plain & Up to $+140 \mu \mathrm{g} \mathrm{m}^{-3}$ \\
\hline Gao et al. (2015) & 10-15 January 2013 & $\begin{array}{l}\text { Beijing, Tianjin, and south } \\
\text { Hebei }\end{array}$ & $+10-50 \mu \mathrm{g} \mathrm{m}^{-3}(2 \%-30 \%)$ \\
\hline Wang et al. (2015) & 7-11 July 2008 & $\begin{array}{l}\text { Beijing, Tianjin, Hebei, East } \\
\text { Shanxi, West Shandong, and } \\
\text { North Henan }\end{array}$ & $+14 \%$ \\
\hline Zhang et al. (2015) & January 2013 & $\begin{array}{l}\text { Henan, Hubei, Guangxi, and } \\
\text { Sichuan }\end{array}$ & Maximum $+69.3 \mu \mathrm{g} \mathrm{m}^{-3}$ \\
\hline Ding et al. (2016) & December 2013 & $\begin{array}{l}\text { Eastern China and the Sichuan } \\
\text { Basin }\end{array}$ & Up to $+100 \mu \mathrm{g} \mathrm{m}^{-3}$ \\
\hline Gao et al. (2016) & January 2010 & Shijiazhuang & More than $+20 \mu \mathrm{g} \mathrm{m}^{-3}$ \\
\hline $\begin{array}{l}\text { X. Zhang et al. } \\
(2018 b)\end{array}$ & December 2016 & Beijing & $\begin{array}{l}\text { Around }+84 \% \text { of }\left[\mathrm{PM}_{2.5}\right] \text { during } \\
\text { cumulative explosive growth }\end{array}$ \\
\hline Liu et al. (2018) & 15-21 December 2016 & North China Plain & $+56 \mu \mathrm{g} \mathrm{m}^{-3}$ \\
\hline $\begin{array}{l}\text { X. Zhang et al. } \\
\text { (2018a) }\end{array}$ & 2014 & China & $\begin{array}{l}\text { Over }+16 \% \text { for the daily maximum } \\
{\left[\mathrm{PM}_{2.5}\right]}\end{array}$ \\
\hline Zhong et al. (2018) & $\begin{array}{l}\text { January } 2013 \text {, February } 2014 \text {, } \\
\text { December } 2015 \text {, and December } \\
2016 \text { to } 10 \text { January } 2017\end{array}$ & Beijing & $\begin{array}{l}\text { Over }+70 \% \text { of }\left[\mathrm{PM}_{2.5}\right] \text { during cumu- } \\
\text { lative explosive growth }\end{array}$ \\
\hline
\end{tabular}

crustal species are not considered. Therefore, the inorganic aerosols in this study are predicted using ISORROPIA version 1.7 , calculating the composition and phase state of an ammonium-sulfate-nitrate-water inorganic aerosol in thermodynamic equilibrium with gas-phase precursors (Nenes et al., 1998). In addition, a parameterization of sulfate heterogeneous formation involving aerosol liquid water (ALW) has been developed and implemented into the model, which has successfully reproduced the observed rapid sulfate formation during haze days ( $\mathrm{Li}$ et al., 2017a). The sulfate heterogeneous formation from $\mathrm{SO}_{2}$ is parameterized as a first-order irreversible uptake by ALW surfaces, with a reactive uptake coefficient of $0.5 \times 10^{-4}$ assuming that there is enough alkalinity to maintain the high iron-catalyzed reaction rate.

The OA module is based on the volatility basis set (VBS) approach, with aging and detailed information found in $\mathrm{Li}$ et al. (2011b). The POA components from traffic-related combustion and biomass burning are represented by nine surrogate species with saturation concentrations $\left(C^{*}\right)$ ranging from $10^{-2}$ to $10^{6} \mathrm{gg} \mathrm{m}^{-3}$ at room temperature (Shrivastava et al., 2008) and assumed to be semivolatile and photochemically reactive (Robinson et al., 2007). The SOA formation from each anthropogenic or biogenic precursor is calculated using four semivolatile VOCs with effective saturation con- centrations of $1,10,100$, and $1000 \mu \mathrm{g} \mathrm{m}^{-3}$ at $298 \mathrm{~K}$. The SOA formation via the heterogeneous reaction of glyoxal and methylglyoxal is parameterized as a first-order irreversible uptake by aerosol particles with an uptake coefficient of $3.7 \times 10^{-3}$ (Liggio et al., 2005; Zhao et al., 2006; Volkamer et al., 2007).

A persistent air pollution episode from 5 December 2015 to 4 January 2016 in the NCP is simulated using the WRFChem model. During the study episode, the average hourly $\left[\mathrm{PM}_{2.5}\right]$ in the NCP are approximately $127.9 \mu \mathrm{g} \mathrm{m}^{-3}$, within the fourth grade of National Ambient Air Quality Standards with $\left[\mathrm{PM}_{2.5}\right.$ ] between 115 and $150 \mu \mathrm{g} \mathrm{m}^{-3}$ (moderately polluted, Feng et al., 2016). The persistent and widespread haze pollution episode with high $\left[\mathrm{PM}_{2.5}\right]$ in the NCP provides a suitable case for observation analyses and model simulations to investigate the ARF effect on haze pollution. Figure 1a shows the model simulation domain, and detailed model configurations can be found in Table 2 .

\subsection{Aerosol radiative module}

In the present study, the Goddard shortwave module developed by Chou and Suarez $(1999,2001)$ is employed to take into account the ARF effect on the haze formation. The aerosol radiative module developed by $\mathrm{Li}$ et al. (2011b) has 


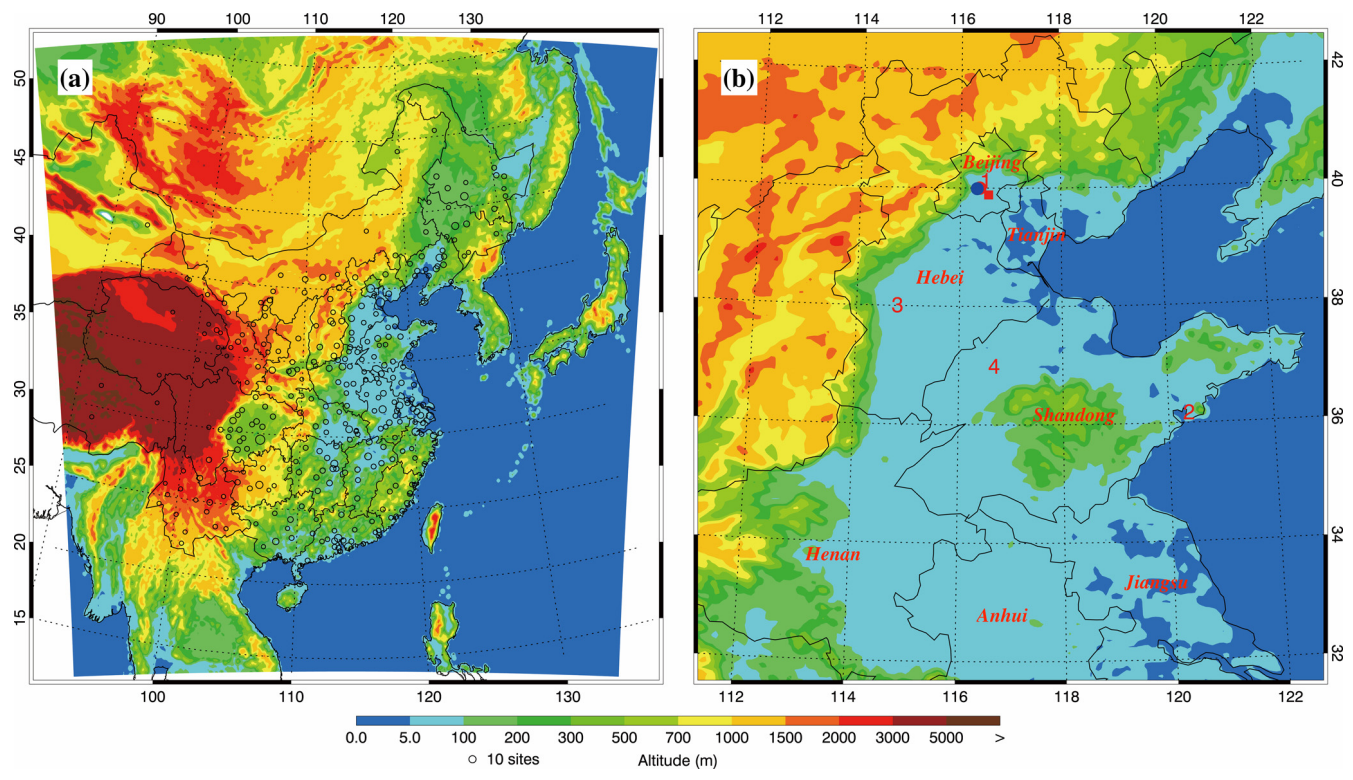

Figure 1. (a) WRF-Chem simulation domain with topography and (b) the Beijing-Tianjin-Hebei area. In (a), the blue circles represent centers of cities with ambient monitoring sites, and the size of blue circles denotes the number of ambient monitoring sites of cities. In (b), the blue and red filled circles denote the NCNST and IRSDE site, respectively; the red filled rectangle denotes the meteorological site. The red numbers denote the CERN sites with the solar radiation measurement. (1) Beijing urban; (2) Jiaozhouwan; (3) Yucheng; (4) Luancheng.

Table 2. WRF-Chem model configurations.

\begin{tabular}{ll}
\hline Region & East Asia \\
\hline Simulation period & 5 December 2015 to 4 January 2016 \\
Domain size & $400 \times 400$ \\
Domain center & $35^{\circ} \mathrm{N}, 114^{\circ} \mathrm{E}$ \\
Horizontal resolution & $12 \mathrm{~km} \times 12 \mathrm{~km}$ \\
Vertical resolution & 35 vertical levels with a stretched vertical grid with spacing ranging from $30 \mathrm{~m}$ \\
& near the surface to 500 m at 2.5 km and $1 \mathrm{~km}$ above 14 km \\
Microphysics scheme & WSM six-class graupel scheme (Hong and Lim, 2006) \\
Cumulus scheme & Grell-Devenyi ensemble scheme (Grell and Devenyi, 2002) \\
Boundary layer scheme & MYJ TKE scheme (Janjić, 2002) \\
Surface layer scheme & MYJ surface scheme (Janjić, 2002) \\
Land-surface scheme & Unified Noah land-surface model (Chen and Dudhia, 2001) \\
Longwave radiation scheme & Goddard longwave scheme (Chou and Suarez, 2001) \\
Shortwave radiation scheme & Goddard shortwave scheme (Chou and Suarez, 1999) \\
Meteorological boundary and initial conditions & NCEP $1^{\circ} \times 1^{\circ}$ reanalysis data \\
Chemical initial and boundary conditions & MOZART 6h output (Horowitz et al., 2003) \\
Anthropogenic emission inventory & Developed by Zhang et al. (2009) and Li et al. (2017b), 2012 base year, and \\
& SAPRC-99 chemical mechanism \\
Biogenic emission inventory & Online MEGAN model developed by Guenther et al. (2006) \\
\hline
\end{tabular}

been incorporated into the WRF-Chem model to calculate the aerosol optical depth (AOD or $\tau_{\mathrm{a}}$ ), single scattering albedo (SSA or $\left.\omega_{\mathrm{a}}\right)$, and the asymmetry factor $\left(g_{\mathrm{a}}\right)$.

In the CMAQ aerosol module, aerosols are represented by a three-moment approach with a lognormal size distribution:

$n(\ln D)=\frac{N}{\sqrt{2 \pi} \ln \sigma_{\mathrm{g}}} \exp \left[-\frac{1}{2}\left(\frac{\ln D-\ln D_{\mathrm{g}}}{\ln \sigma_{\mathrm{g}}}\right)^{2}\right]$, where $D$ is the particle diameter, $N$ is the number distribution of all particles in the distribution, $D_{\mathrm{g}}$ is the geometric mean diameter, and $\sigma_{\mathrm{g}}$ is the geometric standard deviation. To calculate the aerosol optical properties, the aerosol spectrum is first divided into 48 bins from 0.002 to $2.5 \mu \mathrm{m}$, with radius $r_{i}$. The aerosols are classified into four types: (1) internally mixed sulfate, nitrate, ammonium, hydrophilic organics and black carbon, and water; (2) hydrophobic organics; (3) hy- 
drophobic black carbon; and (4) other unidentified aerosols. These four kinds of aerosols are assumed to be mixed externally. For the internally mixed aerosols, the complex refractive index at a certain wavelength $(\lambda)$ is calculated based on the volume-weighted average of the individual refractive index. Given the particle size and complex refractive index, the extinction efficiency $\left(Q_{\mathrm{e}}\right), \omega_{\mathrm{a}}$, and $g_{\mathrm{a}}$ are calculated using the Mie theory at a certain wavelength $(\lambda)$. The lookup tables of $Q_{\mathrm{e}}, \omega_{\mathrm{a}}$, and $g_{\mathrm{a}}$ are established according to particle sizes and refractive indices to avoid multiple Mie scattering calculation. The aerosol optical parameters are interpolated linearly from the lookup tables with the calculated refractive index and particle size in the module.

The aerosol optical depth (AOD or $\tau_{\mathrm{a}}$ ) at a certain wavelength $(\lambda)$ in a given atmospheric layer $k$ is determined by the summation over all types of aerosols and all bins:

$\tau_{\mathrm{a}}(\lambda k)=\sum_{i=1}^{48} \sum_{j=1}^{4} Q_{\mathrm{e}}\left(\lambda r_{i} j k\right) \pi r_{i}^{2} n\left(r_{i} j k\right) \Delta Z_{k}$,

where $n\left(r_{i}, j, k\right)$ is the number concentration of $j$ th kind of aerosols in the $i$ th bin. $\Delta Z_{k}$ is the depth of an atmospheric layer. The weighted-mean values of $\sigma$ and $g$ are then calculated by (d'Almeida et al., 1991)

$$
\begin{aligned}
& \omega_{a}(\lambda k)= \frac{\sum_{i=1}^{48} \sum_{j=1}^{4} Q_{\mathrm{e}}\left(\lambda, r_{i}, j, k\right) \pi r_{i}^{2} n\left(r_{i}, j, k\right)}{\omega_{\mathrm{a}}\left(r_{i}, j, k\right) \Delta Z_{k}}, \\
& \sum_{i=1}^{48} \sum_{j=1}^{4} Q_{e}\left(\lambda, r_{i}, j, k\right) \pi r_{i}^{2} n\left(r_{i}, j, k\right) \Delta Z_{k} \\
& g_{\mathrm{a}}(\lambda k)= \frac{\omega_{i=1}^{48} \sum_{j=1}^{4} Q_{\mathrm{e}}\left(\lambda, r_{i}, j, k\right) \pi r_{i}^{2} n\left(r_{i}, j, k\right)}{\sum_{i=1}^{48} \sum_{j=1}^{4} Q_{\mathrm{e}}\left(\lambda, r_{i}, j, k\right) \pi r_{i}^{2} n\left(r_{i}, j, k\right)}, \\
& \omega_{\mathrm{a}}\left(r_{i}, j, k\right) \Delta Z_{k}
\end{aligned}
$$

When the wavelength-dependent $\tau_{\mathrm{a}}, \omega_{\mathrm{a}}$, and $g_{\mathrm{a}}$ are calculated, they can be used in the Goddard shortwave module to evaluate the ARF. Detailed information can be found in $\mathrm{Li}$ et al. (2011b).

\subsection{Data and statistical methods for comparisons}

The model performance is validated using the available measurements in the NCP, including AOD, SSA, PBLH, downward shortwave flux (SWDOWN), aerosol species, and air pollutants. The daily AOD is retrieved from Terra and Aqua Moderate Resolution Imaging Spectroradiometer (MODIS) level 2 products, with a resolution of $0.1^{\circ} \times 0.1^{\circ}$. The hourly SSA is calculated using the measurement of the turbidity meter at the National Center for Nanoscience and Technology (NCNST), Chinese Academy of Sciences $\left(116.33^{\circ} \mathrm{E}\right.$, $39.99^{\circ} \mathrm{N}$ ), in Beijing (Fig. 1b). The daily PBLH at 12:00 Beijing time (BJT) is diagnosed from the radiosonde observation at a meteorological site $\left(116.47^{\circ} \mathrm{E}, 39.81^{\circ} \mathrm{N}\right)$ in Beijing. The SWDOWN is measured by CM-11 pyranometers at four sites from the Chinese Ecosystem Research Network (CERN) in the NCP (Liu et al., 2016). The hourly measurements of $\mathrm{O}_{3}$,
$\mathrm{NO}_{2}, \mathrm{SO}_{2}, \mathrm{CO}$ and $\mathrm{PM}_{2.5}$ concentrations have been released by China's Ministry of Ecology and Environment (China MEP) since 2013. The hourly submicron sulfate, nitrate, ammonium, and organic aerosols are measured by the Aerodyne Aerosol Chemical Speciation Monitor (ACSM) at NCNST. The primary organic aerosol (POA) and SOA concentrations are obtained from the ACSM measurement analyzed using the positive matrix factorization (PMF). In addition, we have also analyzed the relationship between near-surface $\left[\mathrm{PM}_{2.5}\right]$ and the PBLH retrieved from the lidar measurement at the Institute of Remote Sensing and Digital Earth (IRSDE), Chinese Academy of Sciences $\left(116.38^{\circ} \mathrm{E}, 40.00^{\circ} \mathrm{N}\right)$, in Beijing (Fig. 1b).

In the present study, the mean bias (MB), root mean square error (RMSE), and the index of agreement (IOA) are used to assess the performance of WRF-Chem model simulations against measurements. The detailed description can be found in the Supplement.

\section{Results and discussions}

\subsection{Model performance}

We first define the base simulation in which ARF is considered (hereafter referred to as $f_{\text {base }}$ ), and results from $f_{\text {base }}$ are compared to observations in the NCP. Generally, the model simulates the horizontal distributions and temporal variations of $\mathrm{PM}_{2.5}, \mathrm{O}_{3}, \mathrm{NO}_{2}$, and $\mathrm{SO}_{2}$ mass concentrations against measurements in the NCP well. Additionally, the model also reproduces the temporal profiles of the aerosol species reasonably well compared to observations in Beijing. The detailed model validation of air pollutants in the NCP and the aerosol species in Beijing can be found in the Supplement.

\subsubsection{Aerosol radiative property simulations in the NCP}

Aerosol radiative forcing mainly depends on the AOD, SSA, and asymmetry parameter $(g)$. The model validations of AOD and SSA are provided in this study to further evaluate the aerosol radiative effect on the air pollution. The daily AOD at $550 \mathrm{~nm}$, retrieved from Terra and Aqua MODIS level 2 products, is compared with the simulation. Figure $2 \mathrm{a}$ shows the scatter plot of the daily retrieved and simulated AOD averaged in the NCP from 5 December 2015 to 4 January 2016. The simulated daily average AOD correlates well with the observation, with a correlation coefficient of 0.86 . Generally, the retrieved and simulated AOD increases with deterioration of the haze pollution, but the model considerably underestimates the AOD against the observation. Figure $2 \mathrm{~b}$ presents the Taylor diagram (Taylor, 2001) to show the variance, bias, and correlation of the simulated and retrieved AOD from 5 December 2015 to 4 January 2016. There exists a good relationship between the simulated and retrieved daily AOD during the study episode, with correlation coef- 

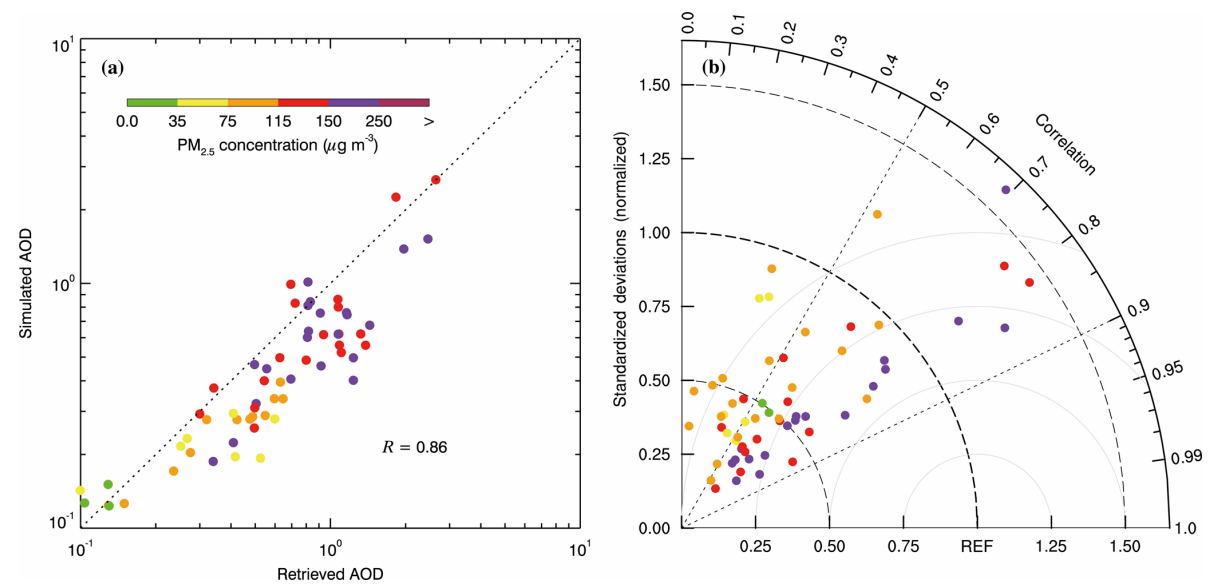

Figure 2. (a) Scatter plot of the MODIS-retrieved and simulated daily AOD; (b) Taylor diagram (Taylor, 2001) to present the variance, bias, and correlation of the retrieved and simulated daily AOD averaged in the NCP from 5 December 2015 to 4 January 2016.

ficients generally ranging from 0.5 to 0.9 and standard deviation mostly varying from 0.25 to 1.0 . Figure 3 shows the pattern comparison of the retrieved and simulated AOD averaged during the simulation period. The model reasonably reproduces the AOD distribution compared to the observations in the NCP but considerably underestimates the AOD. The simulated and retrieved AOD averaged in the NCP during the simulation period is 0.43 and 0.59 , respectively. It is worth noting that the simulated AOD is not only dependent on the column aerosol content and constituent, but is also significantly influenced by the relative humidity $(\mathrm{RH})$ controlling the aerosol hydroscopic growth. Additionally, the satellite-retrieved AOD is subject to contamination by the existence of clouds, and considering the high occurrence frequency of clouds during haze days, the retrieved AOD is generally higher than the simulation (Engstrom and Ekman, 2010; Chand et al., 2012; Grandey et al., 2013).

Aerosols are the mixture of absorbing and scattering constituents in the atmosphere. Their radiative effect of cooling or warming the atmosphere relies on many parameters, and SSA is one of the most important ones (Satheesh et al., 2010). Figure 4 depicts the comparison of the measured and simulated diurnal profiles of SSA at NCNST in Beijing during the episodes. The model performs reasonably in simulating the daily variation of SSA in Beijing, with an IOA of 0.69 and a $\mathrm{MB}$ of 0.0 , but the overestimation or underestimation is rather large. SSA is the ratio of scattering to extinction, which is highly sensitive to the relative distribution of scattering and absorbing aerosol constituents in the atmosphere, as well as the RH determining the hygroscopic growth of aerosols. Therefore, the uncertainties of the simulated SSA probably originated from the model biases of aerosol constituents and the RH.

\subsubsection{Downward solar radiation simulations in the North China Plain}

Figure 5 presents the daily profiles of simulated and observed SWDOWN at ground surfaces in Beijing, Jiaozhouwan, Luancheng, and Yuancheng from 5 December 2015 to 4 January 2016. The WRF-Chem model simulates the daily variation of SWDOWN well, especially in Jiaozhouwan, Luancheng, and Yucheng, with IOAs around 0.90. The model is subject to overestimating the SWDOWN against measurements, with MBs ranging from 6.3 to $86.2 \mathrm{~W} \mathrm{~m}^{-2}$. The SWDOWN reaching the ground surface is very sensitive to the cloud cover and optical thickness. However, the WRFChem model still has difficulties in accurately predicting the cloud cover and optical thickness, which might constitute one of the most important reasons for model biases of the SWDOWN. In addition, the horizontal resolution used in simulations cannot adequately resolve the cumulus clouds, also causing uncertainties in the simulations of the SWDOWN.

\subsubsection{PBLH simulations in Beijing}

Figure 6 shows the temporal variations of the observed and simulated PBLH at a meteorological site in Beijing from 5 December 2015 to 4 January 2016. The average PBLH at 12:00 BJT during the episode at the meteorological site is $465.2 \mathrm{~m}$, with the minimum of $101.8 \mathrm{~m}$ and the maximum of $1017.9 \mathrm{~m}$, showing decreased PBLH during the haze episode. In general, the WRF-Chem model tracks the daily variation of the PBLH in Beijing reasonably, with an IOA of 0.70 . However, the model has difficulties in reproducing the observed very low PBLH, e.g., less than $200 \mathrm{~m}$. The PBLH varies substantially with time due to many factors, including large-scale dynamics, cloudiness, convective mixing, and the diurnal cycle of solar radiation (Sivaraman et al., 2013). Therefore, the simulation uncertainties of meteo- 

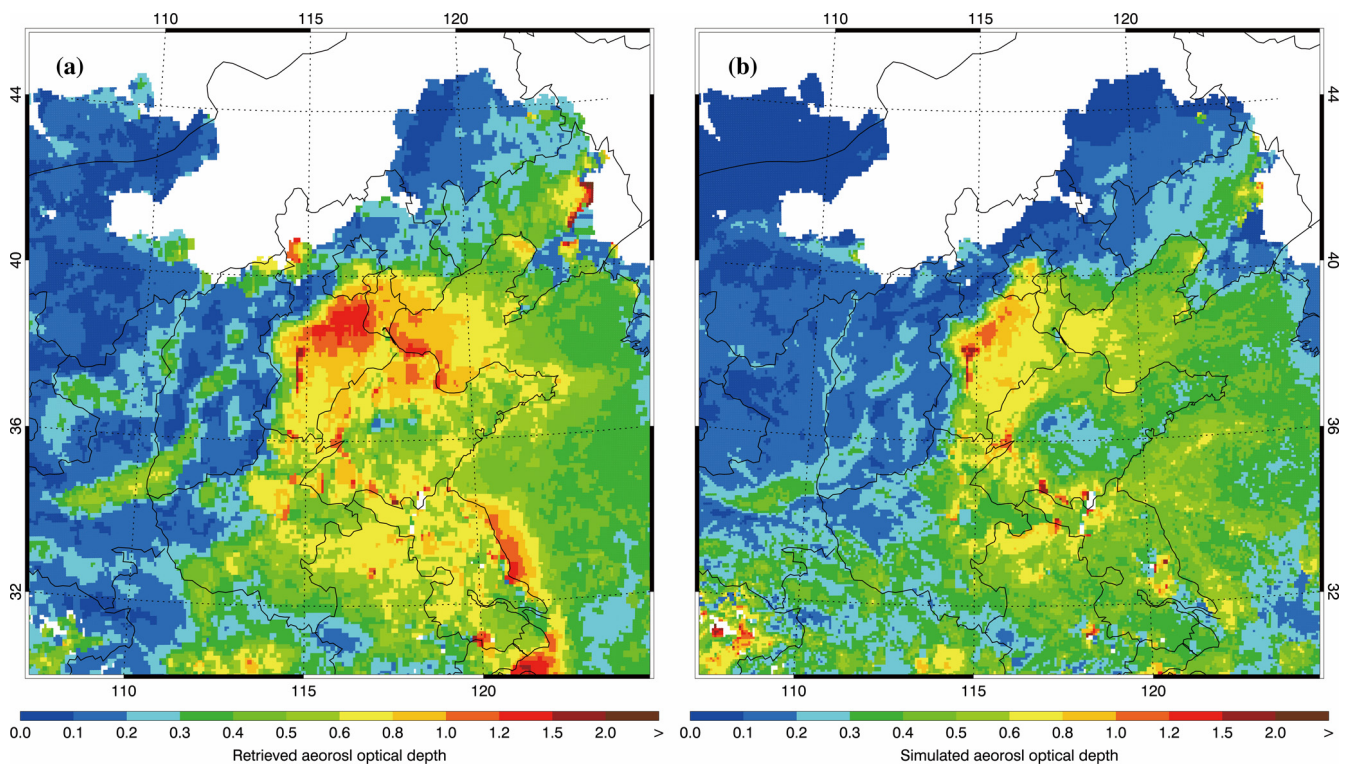

Figure 3. Spatial distribution of (a) retrieved and (b) simulated AOD averaged from 5 December 2015 to 4 January 2016 in the NCP.

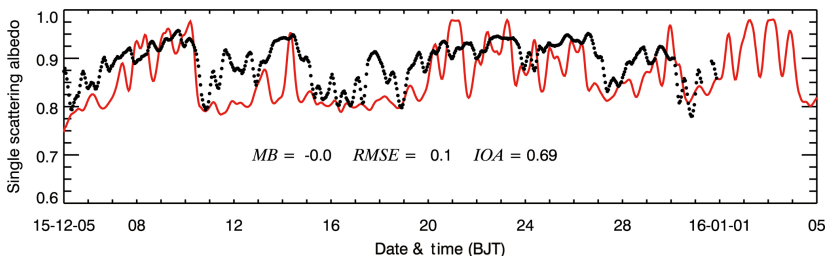

Figure 4. Comparison of measured (black dots) and predicted (red line) diurnal profiles of SSA in Beijing from 5 December 2015 to 4 January 2016.

rological conditions constitute the main reason for the simulation bias of PBLH. For example, the overestimation of SWDOWN at 12:00 BJT (Fig. 5a) probably caused the overestimation of PBLH in Beijing.

In general, the simulated variations of SWDOWN, PBLH, aerosol radiative properties, air pollutants $\left(\mathrm{PM}_{2.5}, \mathrm{O}_{3}, \mathrm{NO}_{2}\right.$, $\mathrm{SO}_{2}, \mathrm{CO}$ ), and aerosol species are in good agreement with observations, indicating that the simulations of meteorological conditions, chemical processes, and the emission inventory used in the WRF-Chem model are reasonable, providing a reliable basis for the further investigation.

\subsection{Relationship between near-surface $\left[\mathrm{PM}_{2.5}\right]$ and PBLH}

Figure 7 presents the scatter plot of the lidar-retrieved PBLH at IRSDE and near-surface $\left[\mathrm{PM}_{2.5}\right]$ at a monitoring site close to IRSDE during daytime (08:00-17:00 LT) from 8 January to 20 February 2014. The wind speeds (WSPD) at a meteorological site close to IRSDE are shown by the color of the filled circles in Fig. 7. Additionally, near-surface $\left[\mathrm{PM}_{2.5}\right]$

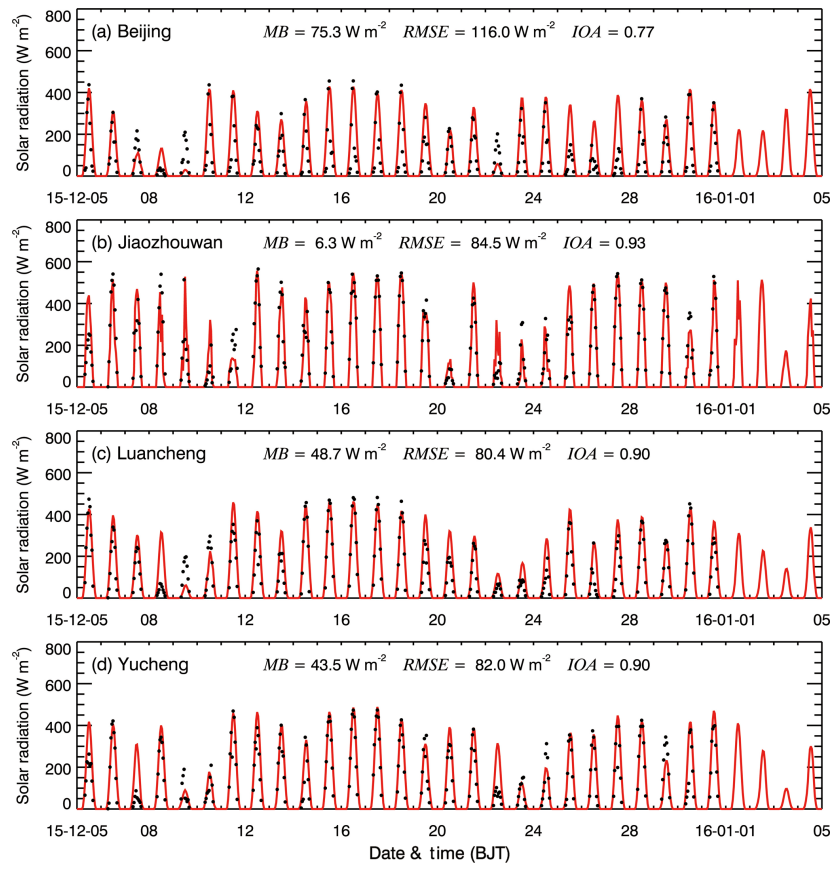

Figure 5. Comparison of measured (black dots) and predicted (red line) diurnal profiles of the SWDOWN reaching the ground surface in (a) Beijing, (b) Jiaozhouwan, (c) Luancheng, and (d) Yucheng from 5 December 2015 to 4 January 2016.

during daytime are also subdivided into 20 bins with the interval of $25 \mu \mathrm{g} \mathrm{m}^{-3}$. The PBLH as the bin of near-surface $\left[\mathrm{PM}_{2.5}\right]$ is assembled, and an average of PBLH in each bin is calculated (Nakajima et al., 2001; Kawamoto et al., 2006), which is represented by the rectangle in Fig. 7. Generally, on average, when the PBLH decreases from 1500 to 


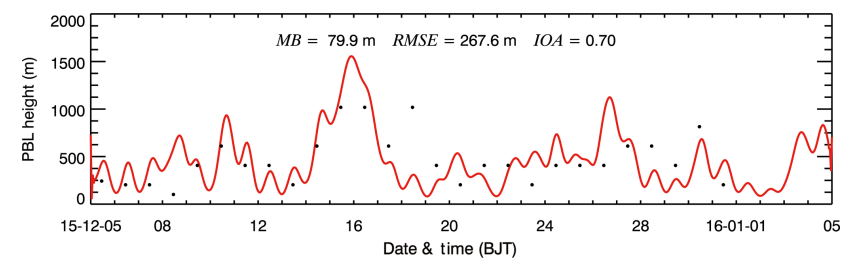

Figure 6. Comparison of predicted diurnal profile (red line) of PBLH from 5 December 2015 to 4 January 2016 with observations at 12:00 BJT in Beijing.

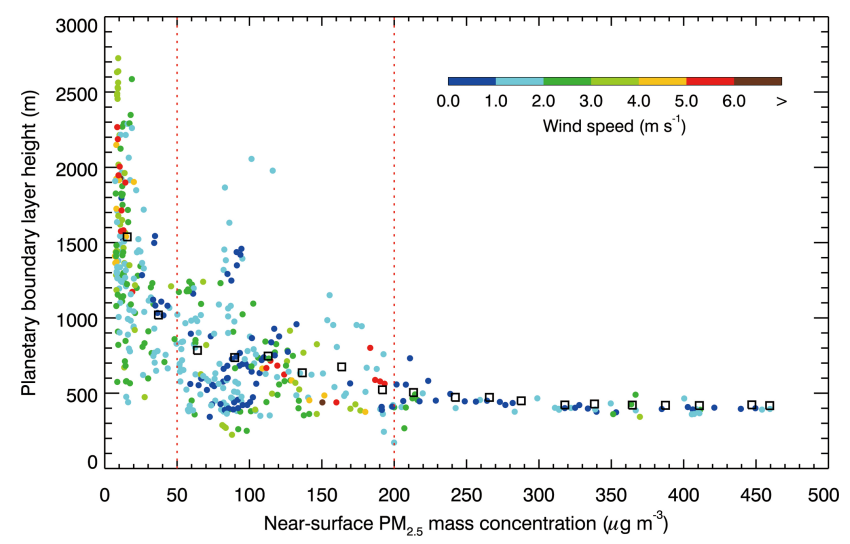

Figure 7. Scatter plot of the PBLH and near-surface $\left[\mathrm{PM}_{2.5}\right]$ at the IRSDE site from 12 January to 20 February 2014. The black rectangle shows the bin average of PBLH. The color of the filled circles denotes the WSPD at the meteorological site close to IRSDE in Fig. 1b.

around $400 \mathrm{~m}$, the near-surface $\left[\mathrm{PM}_{2.5}\right]$ increase from 10 to more than $200 \mu \mathrm{g} \mathrm{m}^{-3}$. When near-surface $\left[\mathrm{PM}_{2.5}\right]$ exceed $200 \mu \mathrm{g} \mathrm{m}^{-3}$, the PBLH remains $400-500 \mathrm{~m}$. Previous studies have also reported the nonlinear relationship between the PBLH and near-surface $\left[\mathrm{PM}_{2.5}\right]$ and proposed that increasing $\left[\mathrm{PM}_{2.5}\right]$ reduce the PBLH or the ARF is attributed to the PBLH decrease (e.g., Petäjä et al., 2016; Tie et al., 2017; Liu et al., 2018).

The PBLH is primarily determined by the wind shear in the vertical direction and the thermal condition of ground surfaces. The occurrence of low near-surface $\left[\mathrm{PM}_{2.5}\right]$ generally corresponds to efficient dispersions of $\mathrm{PM}_{2.5}$ in horizontal and/or vertical directions. The strong horizontal winds in the lower atmosphere not only disperse $\mathrm{PM}_{2.5}$ emitted or formed efficiently, but also intensify the wind shear in the vertical direction, increasing the PBLH and facilitating the rapid vertical exchange of $\mathrm{PM}_{2.5}$ in the PBL. When near-surface $\left[\mathrm{PM}_{2.5}\right]$ are less than $50 \mu \mathrm{g} \mathrm{m}^{-3}$, the PBLH exceeding $1000 \mathrm{~m}$ is observed, which is chiefly determined by strong horizontal winds and less influenced by the ground thermal condition during wintertime, and the observed average WSPD is about $2.4 \mathrm{~m} \mathrm{~s}^{-1}$. The occurrence of high nearsurface $\left[\mathrm{PM}_{2.5}\right]$ indicates that the lower atmosphere is stable or stagnant, with weak horizontal winds and inactive con- vections, hindering the dispersion of $\mathrm{PM}_{2.5}$ in the horizontal and vertical directions. Additionally, as the horizontal winds become weak or calm, the wind shear in the vertical direction is diminished and the PBLH is dominated by the ground thermal condition. When near-surface $\left[\mathrm{PM}_{2.5}\right]$ increase from 50 to around $200 \mu \mathrm{g} \mathrm{m}^{-3}$, the PBLH decreases from around 700 to $400 \mathrm{~m}$, and the average WSPD decreases to $1.8 \mathrm{~m} \mathrm{~s}^{-1}$. However, the increased $\mathrm{PM}_{2.5}$ reducing PBLH still cannot be fully attributed to ARF, which is more likely caused by the decrease in winds or the formation of stagnant situations in the low-level atmosphere. When near-surface $\left[\mathrm{PM}_{2.5}\right]$ exceed $200 \mathrm{\mu g} \mathrm{m}^{-3}$, the observed PBLH fluctuates between 400 and $500 \mathrm{~m}$ with the average WSPD of around $1.0 \mathrm{~m} \mathrm{~s}^{-1}$ and does not exhibit a continuous decrease with the increasing nearsurface $\left[\mathrm{PM}_{2.5}\right]$.

Under the stagnant situation with weak winds, the PBLH is more sensitive to the ground thermal condition. Increasing aerosols or $\mathrm{PM}_{2.5}$ in the low-level atmosphere attenuate the SWDOWN to the ground surface and decrease the surface temperature (TSFC) and turbulence kinetic energy, suppressing the PBL development and further enhancing nearsurface $\left[\mathrm{PM}_{2.5}\right]$. Therefore, with near-surface $\left[\mathrm{PM}_{2.5}\right]$ exceeding $200 \mu \mathrm{g} \mathrm{m}^{-3}$, the inert PBLH might be caused by the defect of the lidar-retrieved PBLH. The aerosol backscatter signal received by lidar is used to retrieve the PBLH. If the atmosphere is stable, the aerosols near the maximal PBLH are subject to being confined in situ, and the retrieved PBLH is generally the maximal one. Additionally, it is worth noting that the occurrence of the wintertime severe haze pollution in the NCP is often accompanied with the high-level convergence between 500 and $700 \mathrm{hPa}$, producing a persistent and strong sinking motion in the middle lower troposphere to reduce the PBLH and facilitate accumulation of air pollutants (Wu et al., 2017; Ding et al., 2017). Therefore, a subsidence inversion appears in the lower layer as a result of the air masses sinking in the middle troposphere, restraining the PBL development and determining the maximal PBLH. Hence, it is imperative to evaluate the contribution of ARF to the PBLH and near-surface $\left[\mathrm{PM}_{2.5}\right]$.

\subsection{Sensitivity studies}

The conceptual model about the ARF contribution to the heavy haze formation has been established in previous studies (e.g., Tie et al., 2017; Liu et al., 2018). During wintertime, under stagnant meteorological situations with weak winds and humid air, air pollutants are subject to accumulation in the PBL, facilitating the formation of $\mathrm{PM}_{2.5}$. Increasing $\mathrm{PM}_{2.5}$ in the PBL absorbs or scatters the incoming solar radiation to decrease the TSFC and facilitate anomalous temperature inversion, subsequently suppressing the vertical turbulent diffusion and decreasing the PBLH to further trap more air pollutants and water vapor to increase the RH in the PBL. Increasing RH enhances aerosol hygroscopic growth and multiphase reactions and augments the particle size and 
mass, causing further dimming and decrease in the TSFC and PBLH. The whole process constitutes a positive feedback induced by the aerosol radiation effect to enhance near-surface $\left[\mathrm{PM}_{2.5}\right]$, which has been proposed in many studies (Quan et al., 2013; Petäjä et al., 2016; Yang et al., 2016; Tie et al., 2017; Ding et al., 2017; Liu et al., 2018). The noted positive meteorological condition feedback has also been considered as the main reason for the near-surface $\mathrm{PM}_{2.5}$ explosive growth (Zhong et al., 2018; X. Zhang et al., 2018b).

To comprehensively evaluate the influence of ARF on near-surface $\left[\mathrm{PM}_{2.5}\right]$ during the haze episode, a sensitivity study in which ARF is turned off has been conducted (hereafter referred as $f_{\mathrm{rad} 0}$ ). Therefore, the contribution of ARF to near-surface $\left[\mathrm{PM}_{2.5}\right]$ can be determined by the difference between $f_{\text {base }}$ and $f_{\text {rad } 0}\left(f_{\text {base }}-f_{\text {rad } 0}\right)$. The most polluted area in the NCP is first selected to verify the conceptual model of the ARF contribution to the heavy haze formation, with the average near-surface $\left[\mathrm{PM}_{2.5}\right]$ during the haze episode exceeding $150 \mu \mathrm{g} \mathrm{m}^{-3}$. Figure 8 provides the temporal variation of near-surface $\left[\mathrm{PM}_{2.5}\right.$ ], SWDOWN, TSFC, PBLH, and $\mathrm{RH}$ averaged in the selected area during the episode in $f_{\text {base }}$ and $f_{\text {rado }}$. Apparently, ARF considerably decreases the solar radiation reaching the ground surface and correspondingly lowers the TSFC (Fig. 8b and c). Subsequently, the PBLH is decreased and the surface RH is increased due to decreasing TSFC during daytime (Fig. 8d and e). However, the variation trend of near-surface $\left[\mathrm{PM}_{2.5}\right], \mathrm{PBLH}, \mathrm{TSFC}$, and $\mathrm{RH}$ due to ARF is not similar to that proposed in the conceptual model. During the haze development stage, whether ARF is considered or not, the TSFC and RH exhibit an increasing trend, showing the air mass originated from the south, and the PBLH does not consistently decrease with increasing near-surface $\left[\mathrm{PM}_{2.5}\right]$. Additionally, the ARF contribution to near-surface $\left[\mathrm{PM}_{2.5}\right]$ is generally marginal during the haze development stage. During the haze maturation stage, ARF commences to elevate near-surface $\left[\mathrm{PM}_{2.5}\right]$ appreciably. It is worth noting that, even if ARF is not considered in $f_{\text {rad0 }}$, the heavy haze pollution still occurs during the episode. For example, from 17 to 20 December 2015, without ARF, near-surface $\left[\mathrm{PM}_{2.5}\right]$ still continue to increase from around 30 to $300 \mu \mathrm{g} \mathrm{m}^{-3}$ and fluctuate between 150 and $300 \mu \mathrm{g} \mathrm{m}^{-3}$ until the occurrence of favorable meteorological conditions on 25 December. Hence, according to the variation trend of near-surface $\left[\mathrm{PM}_{2.5}\right]$ with and without the ARF contribution, the continuous accumulation of $\mathrm{PM}_{2.5}$ during the haze episode is not primarily caused by ARF but predominantly induced by the stagnant meteorological conditions as well as the massive air pollutant emissions in the NCP. Figure 9 presents the temporal variation of AOD at $550 \mathrm{~nm}$ averaged in the selected area during the episode in $f_{\text {base }}$ and $f_{\text {rad0 }}$ to evaluate the impact of ARF on AOD. Apparently, except from 8 to 11 December, the ARF contribution to AOD is generally marginal, indicating that ARF does not play an important role in the column-integrated aerosol abundance. Additionally, the considerable AOD enhancement from 8 to
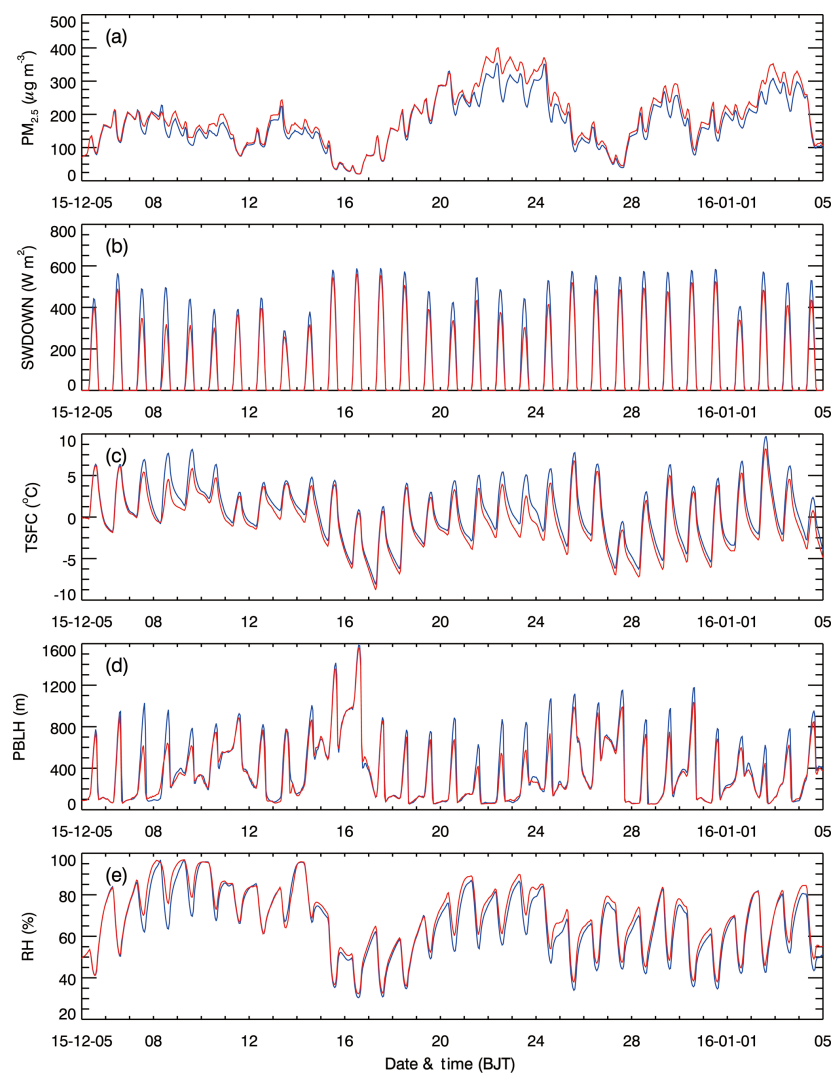

Figure 8. Temporal variations of the average (a) near-surface $\left[\mathrm{PM}_{2.5}\right]$, (b) SWDOWN at the ground surface, (c) TSFC, (d) PBLH, and (e) $\mathrm{RH}$ in the most polluted area in the NCP with $\left[\mathrm{PM}_{2.5}\right]$ of more than $150 \mu \mathrm{g} \mathrm{m}^{-3}$ in $f_{\text {base }}$ (red solid line) and $f_{\text {rad0 }}$ (blue solid line) from 5 December 2015 to 4 January 2016.

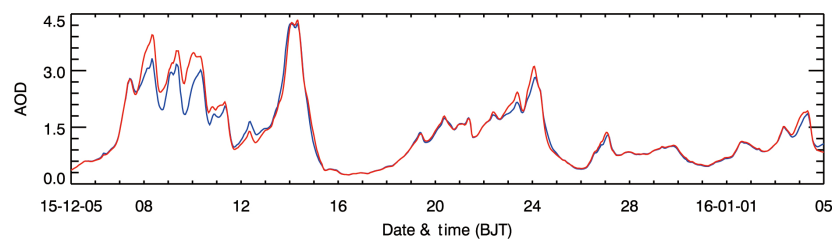

Figure 9. Temporal variations of the average AOD at $550 \mathrm{~nm}$ in the most polluted area in the $\mathrm{NCP}$ with $\left[\mathrm{PM}_{2.5}\right]$ of more than $150 \mu \mathrm{g} \mathrm{m}^{-3}$ in $f_{\text {base }}$ (red solid line) and $f_{\text {rad0 }}$ (blue solid line) from 5 December 2015 to 4 January 2016.

11 December is more likely caused by the substantial increase in RH due to ARF, which facilitates aerosol hygroscopic growth to augment particle size and further increases AOD. It is worth noting that the extinction of haze aerosols in the PBL also decreases the photolysis to suppress the photochemistry, further hindering the secondary aerosol formation to offset effects of ARF on near-surface $\left[\mathrm{PM}_{2.5}\right]$.

In order to quantitatively evaluate effects of ARF on nearsurface $\left[\mathrm{PM}_{2.5}\right]$, which cannot be reflected by the temporal variation of near-surface $\left[\mathrm{PM}_{2.5}\right]$, TSFC, $\mathrm{PBLH}$, and $\mathrm{RH}$, an 

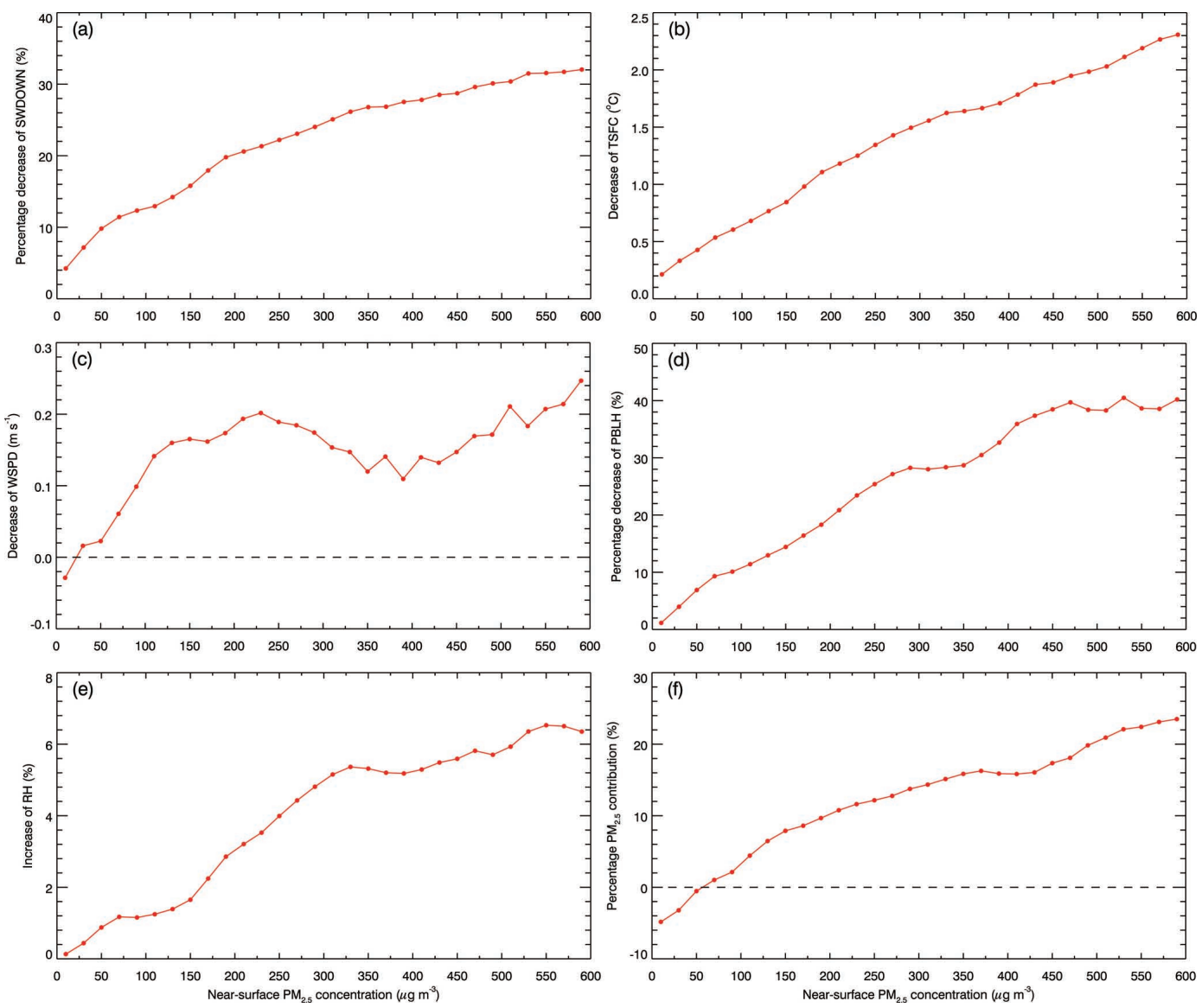

Figure 10. Average (a) percentage decrease in SWDOWN at the ground surface, (b) decrease in TSFC, (c) decrease in WSPD, (d) percentage decrease in PBLH, (e) increase of RH, and (f) percentage contribution of near-surface $\left[\mathrm{PM}_{2.5}\right]$ caused by ARF, as a function of the nearsurface $\left[\mathrm{PM}_{2.5}\right]$ in the NCP during daytime from 5 December 2015 to 4 January 2016.

ensemble method is used in this study. The daytime nearsurface $\left[\mathrm{PM}_{2.5}\right]$ in the $\mathrm{NCP}$ during the episode in $f_{\text {base }}$ are first subdivided into 30 bins with an interval of $20 \mu \mathrm{g} \mathrm{m}^{-3}$. The SWDOWN, TSFC, PBLH, the near-surface WSPD, RH, and $\left[\mathrm{PM}_{2.5}\right]$ in $f_{\text {base }}$ and $f_{\text {rado } 0}$ in the same grid cell are assembled as the bin $\left[\mathrm{PM}_{2.5}\right]$, respectively, and an average of these variables in each bin is calculated. Figure 10 shows the decrease in SWDOWN (\%), TSFC $\left({ }^{\circ} \mathrm{C}\right)$, PBLH $(\%)$, WSPD $\left(\mathrm{m} \mathrm{s}^{-2}\right)$ and the increase of RH (\%, not percentage change) and near-surface $\left[\mathrm{PM}_{2.5}\right]$ contribution (\%) caused by ARF as a function of bin $\left[\mathrm{PM}_{2.5}\right]$. The SWDOWN reaching the ground surface almost decreases linearly with the enhancement of near-surface $\left[\mathrm{PM}_{2.5}\right]$. When ARF is considered, aerosols in the atmosphere absorb or scatter the incoming solar radiation, directly attenuating the radiation reaching the ground surface. When near-surface $\left[\mathrm{PM}_{2.5}\right]$ exceed $200 \mu \mathrm{g} \mathrm{m}^{-3}$, the SWDOWN at ground surfaces decreases by more than $20 \%$ (Fig. 10a). Moreover, the decrease in the SWDOWN correspondingly lowers the TSFC, and the decrease in the TSFC is generally proportional to near-surface $\left[\mathrm{PM}_{2.5}\right]$, about $0.35^{\circ} \mathrm{C}$ per $100 \mu \mathrm{m} \mathrm{m}^{-3} \mathrm{PM}_{2.5}$ (Fig. 10b).
Interestingly, ARF also decreases near-surface WSPD by about $0.1-0.2 \mathrm{~m} \mathrm{~s}^{-1}$ with near-surface $\left[\mathrm{PM}_{2.5}\right]$ exceeding $80 \mu \mathrm{m} \mathrm{m}^{-3}$ (Fig. 10c). When severe air pollution occurs in the NCP during wintertime, atmospheric convergence occurs in the PBL (Liao et al., 2015; Ding et al., 2017). However, the ARF-induced cooling in the low-level air generates a divergence in the NCP, causing the decrease in near-surface WSPD.

The PBLH is primarily determined by the atmospheric dynamic and thermal condition of ground surfaces. Therefore, the decrease in WSPD and TSFC due to ARF subsequently suppresses the PBL development and diminishes the PBLH (Fig. 10d). When near-surface $\left[\mathrm{PM}_{2.5}\right]$ are less than $250 \mu \mathrm{g} \mathrm{m}^{-3}$, the PBLH decreases rapidly with increasing $\left[\mathrm{PM}_{2.5}\right]$. When the near-surface $\left[\mathrm{PM}_{2.5}\right]$ are between 250 and $350 \mu \mathrm{g} \mathrm{m}^{-3}$, the decrease in PBLH is around $28 \%$. With near-surface $\left[\mathrm{PM}_{2.5}\right]$ more than $350 \mu \mathrm{g} \mathrm{m}^{-3}$, the decrease in PBLH exceeds $30 \%$. As for the ARF effect on water vapor in the PBL, the conceptual model has proposed that the decreased PBL induced by ARF weakens the vertical exchange of water vapor or the dispersion of water vapor is 

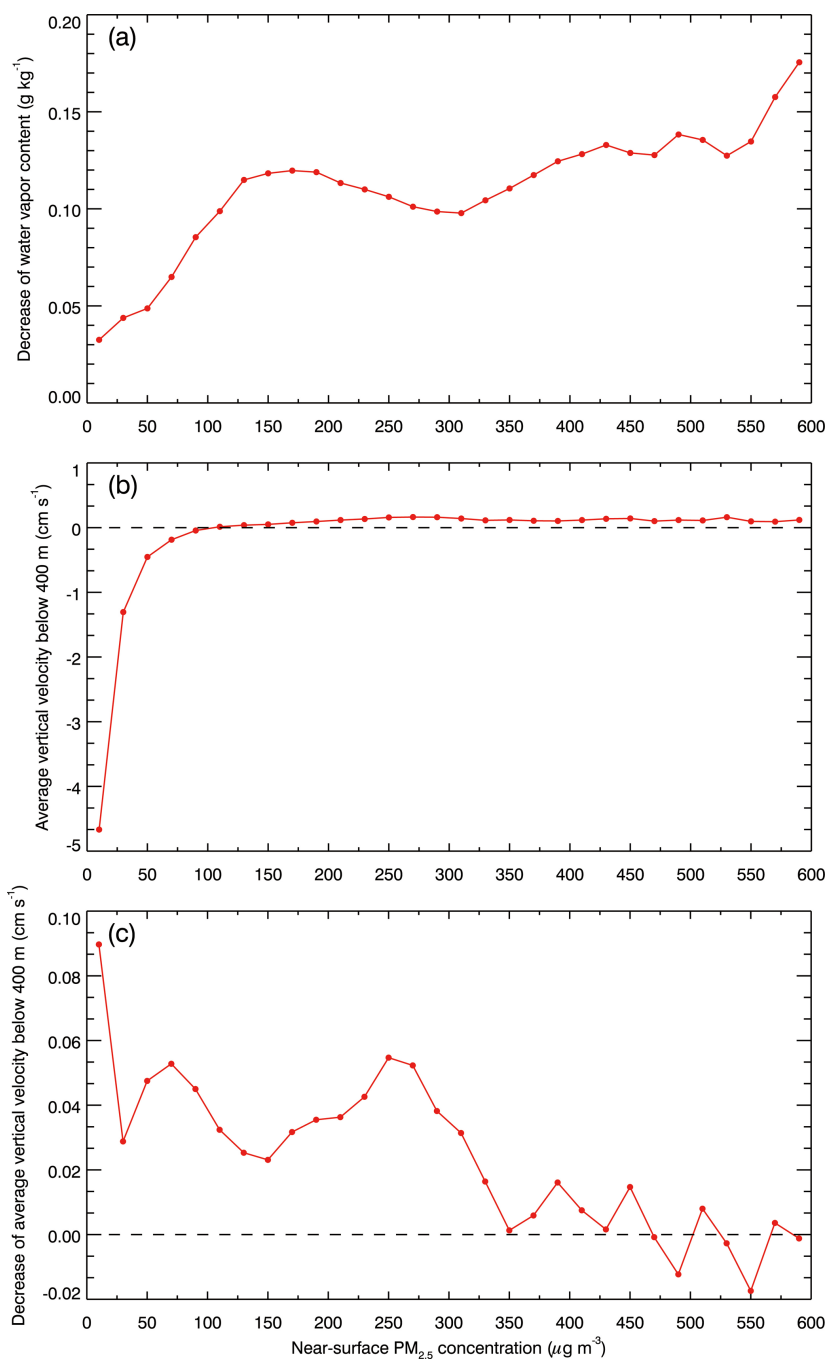

Figure 11. Average decrease in (a) near-surface water vapor content and (c) vertical velocity below $400 \mathrm{~m}$ caused by ARF, and (b) average vertical velocity below $400 \mathrm{~m}$ in $f_{\text {rado } 0}$ as a function of the nearsurface $\left[\mathrm{PM}_{2.5}\right]$ in the NCP during daytime from 5 December 2015 to 4 January 2016.

constrained by the shallow PBL (Tie et al., 2017; Liu et al., 2018). However, Fig. 11a shows that ARF decreases the nearsurface water vapor content slightly, by more than $0.1 \mathrm{~g} \mathrm{~kg}^{-1}$ with near-surface $\left[\mathrm{PM}_{2.5}\right]$ exceeding $100 \mu \mathrm{g} \mathrm{m}^{-3}$. During the haze episode in the NCP, the abundant moisture in the PBL is mainly transported from the south. The divergence due to cooling caused by ARF weakens the prevailing southerly wind and decreases the moisture transport from the south, reducing the water vapor content in the NCP. Considering that the $\mathrm{RH}$ is sensitive to the temperature with a constant water vapor content, the ARF-induced cooling still increases the near-surface RH (Fig. 10e). When near-surface $\left[\mathrm{PM}_{2.5}\right]$ exceed $300 \mu \mathrm{g} \mathrm{m}^{-3}$, the RH is increased by more than $5 \%$, so the heavy haze generally causes the air to be more humid.
More $\mathrm{PM}_{2.5}$ emitted or formed is trapped by a shallow PBL caused by ARF, and increased RH promotes the aerosol hygroscopic growth and further multiphase reactions, progressively enhancing near-surface $\left[\mathrm{PM}_{2.5}\right]$ (Fig. 10f). When near-surface $\left[\mathrm{PM}_{2.5}\right]$ are more than $50 \mu \mathrm{g} \mathrm{m}^{-3}$, the contribution of ARF to near-surface $\left[\mathrm{PM}_{2.5}\right]$ consistently increases with the haze deterioration. When the severe haze occurs, i.e., near-surface $\left[\mathrm{PM}_{2.5}\right]$ exceed $250 \mu \mathrm{g} \mathrm{m}^{-3}$, more than $12 \%$ or $30 \mu \mathrm{g} \mathrm{m}^{-3} \mathrm{PM}_{2.5}$ is contributed by ARF. The simulated ARF effects on near-surface $\left[\mathrm{PM}_{2.5}\right]$ are generally comparable to those reported by previous studies. Z. F. Wang et al. (2014) have shown that ARF increases the monthly $\mathrm{PM}_{2.5}$ concentration by $10 \%-30 \%$ in Beijing-TianjinHebei in January 2013. Using the WRF-Chem model, Gao et al. (2015) have indicated that ARF increases the $\mathrm{PM}_{2.5}$ concentration by $10-50 \mu \mathrm{g} \mathrm{m}^{-3}(2 \%-30 \%)$ over Beijing, Tianjin, and south Hebei from 10 to 15 January 2013, a period with the simulated maximum hourly surface $\mathrm{PM}_{2.5}$ concentration of more than $600 \mu \mathrm{g} \mathrm{m}^{-3}$. X. Zhang et al. (2018a) have also quantified the aerosol-meteorology interaction effect on $\mathrm{PM}_{2.5}$ concentrations in China in 2014 using the WRF-Chem model, showing that the increase of $\mathrm{PM}_{2.5}$ concentrations associated with ARF is up to $16 \%$ in China. Other previous studies have also confirmed the ARF effect during the heavy haze pollution episode (Wang et al., 2015; Zhang et al., 2015; Gao et al., 2016). However, when nearsurface $\left[\mathrm{PM}_{2.5}\right]$ are less than $50 \mu \mathrm{g} \mathrm{m}^{-3}$, the contribution of ARF to near-surface $\left[\mathrm{PM}_{2.5}\right]$ is negative, although ARF decreases PBLH and increases RH. One of the possible reasons for the negative contribution of ARF is perturbations of wind fields caused by the ARF-induced cooling. Figure $11 \mathrm{~b}$ presents the average vertical velocity (the net velocity by combining updrafts and downdrafts) below about $400 \mathrm{~m}$ in $f_{\mathrm{rad} 0}$ as a function of near-surface $\left[\mathrm{PM}_{2.5}\right]$. Apparently, when ARF is not considered, the area with nearsurface $\left[\mathrm{PM}_{2.5}\right]$ less than $100 \mu \mathrm{g} \mathrm{m}^{-3}$ is generally controlled by downward airflow, and vice versa, for the area with nearsurface $\left[\mathrm{PM}_{2.5}\right]$ more than $100 \mu \mathrm{g} \mathrm{m}^{-3}$. The ARF-induced cooling generally causes a downward motion in the PBL (Fig. 11c), which suppresses the upward motion in the area with near-surface $\left[\mathrm{PM}_{2.5}\right]$ more than $100 \mu \mathrm{g} \mathrm{m}^{-3}$ to enhance near-surface $\left[\mathrm{PM}_{2.5}\right]$, but accelerates the downward motion in the area with near-surface $\left[\mathrm{PM}_{2.5}\right]$ less than $100 \mu \mathrm{g} \mathrm{m}^{-3}$ to strengthen the divergence intensity, further decreasing nearsurface $\left[\mathrm{PM}_{2.5}\right]$. Countered by the decrease in PBLH and increase of $\mathrm{RH}$, the ARF contribution becomes positive with near-surface $\left[\mathrm{PM}_{2.5}\right]$ exceeding $50 \mu \mathrm{g} \mathrm{m}^{-3}$.

Figure 12 presents spatial distributions of the average near-surface $\mathrm{PM}_{2.5}$ contribution due to ARF during the episode. The average near-surface $\mathrm{PM}_{2.5}$ contribution caused by ARF in the NCP is $10.2 \mu \mathrm{g} \mathrm{m}^{-3}$ or $7.8 \%$, with the maximum exceeding $40 \mu \mathrm{g} \mathrm{m}^{-3}$ in the south of Hebei. On average, the ARF contribution to near-surface $\left[\mathrm{PM}_{2.5}\right]$ is the most significant in Tianjin, about $17.6 \mu \mathrm{g} \mathrm{m}^{-3}$ or $10.3 \%$, followed by Hebei $\left(11.6 \mu \mathrm{g} \mathrm{m}^{-3}\right.$ or $\left.9.3 \%\right)$, Shandong 

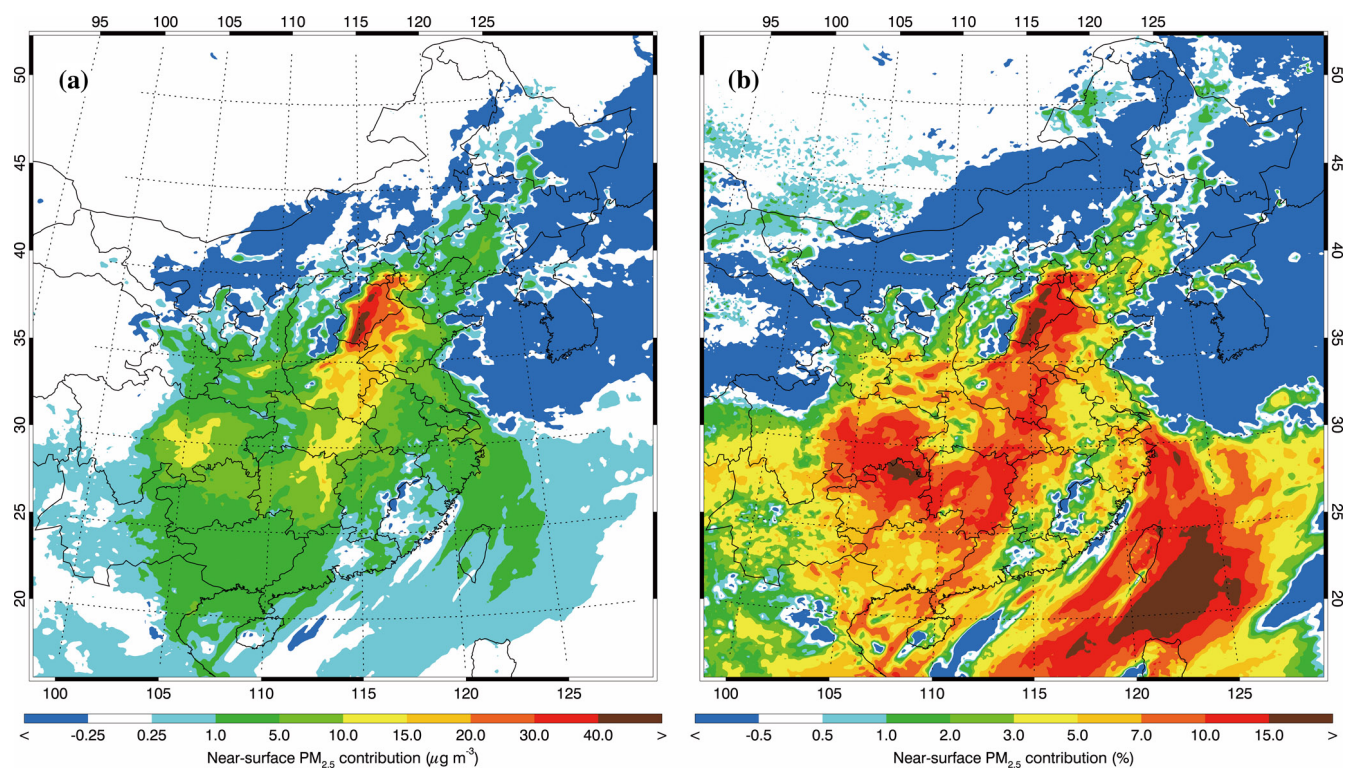

Figure 12. Near-surface $\left[\mathrm{PM}_{2.5}\right]$ contribution caused by ARF, averaged from 5 December 2015 to 4 January 2016 in the NCP.

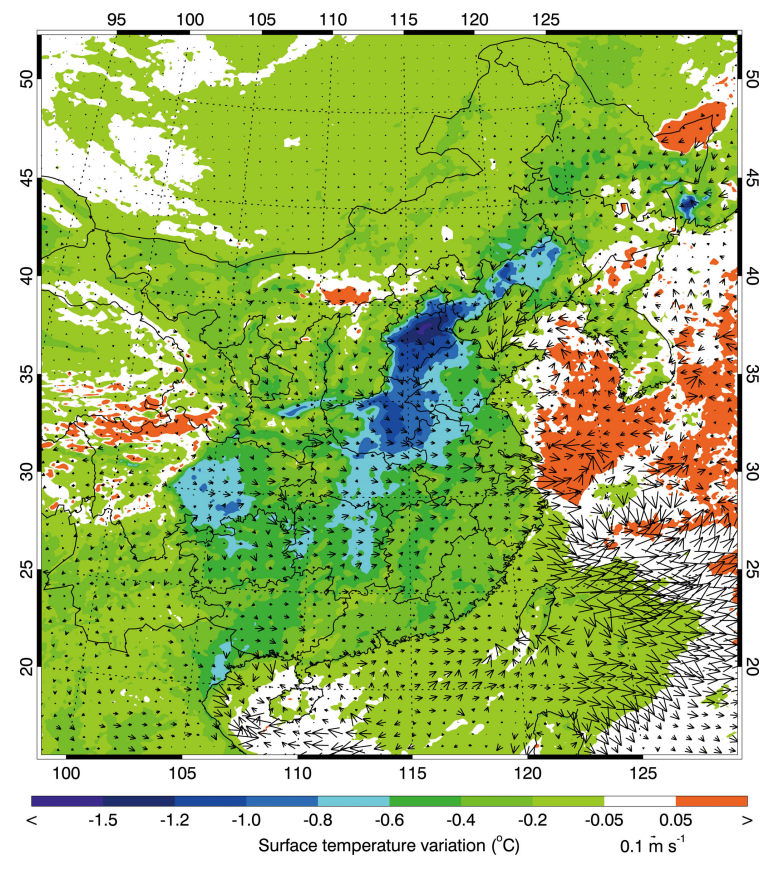

Figure 13. TSFC and wind filed variations caused by ARF, averaged from 5 December 2015 to 4 January 2016 in the NCP.

(11.5 $\mu \mathrm{g} \mathrm{m}^{-3}$ or $\left.7.3 \%\right)$, Henan $\left(11.2 \mu \mathrm{g} \mathrm{m}^{-3}\right.$ or $\left.7.7 \%\right)$, Anhui $\left(7.7 \mu \mathrm{g} \mathrm{m}^{-3}\right.$ or $\left.7.4 \%\right)$, Beijing $\left(7.3 \mu \mathrm{g} \mathrm{m}^{-3}\right.$ or $\left.6.9 \%\right)$, and Jiangsu $\left(7.0 \mu \mathrm{g} \mathrm{m} \mathrm{m}^{-3}\right.$ or $\left.6.2 \%\right)$. It is noteworthy that the ARF contribution during the episode in North China is generally positive, but in its surrounding area the contribution becomes negative. At a large scale, when the air pollution occurs during wintertime in North China, the vertical motion over the polluted area generally shows an ascending-descending- ascending distribution from the surface to the middle level of the troposphere, and wind directions present a structure of convergence-divergence-convergence accordingly (Liao et al., 2015; Wu et al., 2017; Ding et al., 2017). ARF cools the low-level atmosphere and induces a downward motion, which suppresses the upward motion in the convergence area in North China to increase near-surface $\left[\mathrm{PM}_{2.5}\right]$, but accelerates the downward motion in the divergence area to decrease $\left[\mathrm{PM}_{2.5}\right]$.

Furthermore, when ARF is considered, near-surface $\left[\mathrm{PM}_{2.5}\right]$ over the East and South China Sea are also increased, with an enhancement less than $5 \mu \mathrm{g} \mathrm{m}^{-3}$ (about $3 \%$ to more than $15 \%$ ). Considering the low near-surface $\left[\mathrm{PM}_{2.5}\right]$ over sea, the $\left[\mathrm{PM}_{2.5}\right]$ enhancement might be caused by the $\mathrm{PM}_{2.5}$ transport from the continent. Figure 13 shows the spatial distribution of the TSFC and wind field variation caused by ARF averaged during the episode. Apparently, ARF causes a widespread cooling effect in East China, and the cooling is the most significant in the NCP, with the maximum TSFC decrease exceeding $1.5^{\circ} \mathrm{C}$. The cooling effect in the NCP induces a weak northerly wind, decreasing the prevailing southerly wind during the haze episode (Fig. 13). Additionally, the cooling effect over the continent also intensifies the temperature contrast between land and sea, producing a secondary circulation to transport the $\mathrm{PM}_{2.5}$ from the continent to the East and South China Sea.

\section{Conclusions}

In the study, a persistent haze pollution episode in the NCP from 5 December 2015 to 4 January 2016 is simulated using the WRF-Chem model to verify the ARF contribution to 
the haze formation. Generally, the model reproduces the spatial distributions and temporal variations of $\mathrm{PM}_{2.5}, \mathrm{O}_{3}, \mathrm{NO}_{2}$, $\mathrm{SO}_{2}$, and $\mathrm{CO}$ mass concentrations against observations in the NCP well. The calculated temporal variations of aerosol species are also consistent with the ACSM measurement in Beijing, particularly with regard to the simulation of sulfate, nitrate, and ammonium. Moreover, the model simulates the variation of SWDOWN, PBLH, and aerosol radiative properties during the episode reasonably well, compared to the measurement.

Previous studies have established that a positive feedback induced by ARF causes the heavy haze formation by modulating the PBL and RH. However, model results demonstrate that, during the haze development stage in the NCP, ARF does not dominate the accumulation of near-surface $\left[\mathrm{PM}_{2.5}\right]$, while ARF considerably enhances near-surface $\left[\mathrm{PM}_{2.5}\right]$ during the haze mature stage.

Ensemble analyses of model results show that, during daytime, ARF attenuates SWDOWN reaching ground surfaces efficiently, and correspondingly the TSFC progressively decreases with increasing near-surface $\left[\mathrm{PM}_{2.5}\right]$ in the NCP. The ARF-induced cooling generates a divergence in the low-level atmosphere in the NCP, lowering the near-surface WSPD and decreasing the water vapor transport from the south. The decreased WSPD and TSFC caused by ARF hinder the PBL development and the PBLH decreases rapidly with increasing near-surface $\left[\mathrm{PM}_{2.5}\right]$. Although the water content in the NCP is decreased slightly, the RH is still increased due to the ARFinduced cooling. A shallow PBL and more humid air caused by ARF accelerate the $\mathrm{PM}_{2.5}$ accumulation and secondary pollutant formation, facilitating heavy haze formation. The contribution of ARF to near-surface $\left[\mathrm{PM}_{2.5}\right]$ increases from $12 \%$ to $20 \%$ when near-surface $\left[\mathrm{PM}_{2.5}\right]$ increase from 250 to $500 \mu \mathrm{g} \mathrm{m}^{-3}$. However, ARF decreases the $\mathrm{PM}_{2.5}$ level with near-surface $\left[\mathrm{PM}_{2.5}\right]$ less than $50 \mu \mathrm{g} \mathrm{m}^{-3}$.

The average near-surface $\mathrm{PM}_{2.5}$ contribution of ARF during the episode in the NCP is $10.2 \mu \mathrm{g} \mathrm{m}^{-3}$ or $7.8 \%$. ARF aggravates the heavy haze formation in North China, but in its surrounding area ARF slightly mitigates the haze pollution. Generally, there is a structure of convergence-divergenceconvergence over the polluted area of North China from the surface to the middle level of the troposphere. A downward motion is induced due to the widespread cooling effect of the low-level atmosphere caused by ARF, impeding the upward motion in the convergence area in North China to increase near-surface $\left[\mathrm{PM}_{2.5}\right]$ but accelerating the downward motion in the divergence area to decrease $\left[\mathrm{PM}_{2.5}\right]$.

Although the model performs generally well in simulating air pollutants, aerosol species and radiative properties, SWDOWN, and PBLH, the uncertainties from meteorological fields and the emission inventory still have the potential to influence ARF evaluation. In particular, further studies need to be conducted to improve the AOD simulations. In this study, ARF only considers the aerosol effect on the solar radiation, and the influence of longwave radiation also needs to be included. It is worth noting that modification of photolysis by aerosol scattering or absorbing solar radiation ultimately alters the atmospheric oxidizing capacity to influence the secondary aerosol formation, which potentially offsets the ARF effect on the haze pollution. Hence, further studies need to be performed to evaluate the effect of aerosol photolysis interaction on the haze pollution. In addition, aerosols play an important role in the cloud process serving as cloud condensation nuclei (CCN) and ice nuclei (IN). Therefore, aerosolcloud interactions (aerosol indirect effect) modify temperature and moisture profiles and further influence precipitation, leading to potential effects on the atmospheric chemistry (Wang et al., 2011). Future studies should be performed to investigate the feedbacks of the aerosol indirect effect on the air pollutants.

Data availability. The real-time $\mathrm{PM}_{2.5}, \mathrm{O}_{3}, \mathrm{NO}_{2}, \mathrm{SO}_{2}$, and $\mathrm{CO}$ observations are accessible for the public on the website http:// 106.37.208.233:20035/ (last access: 18 October 2018) (China MEP, 2013a). One can also access the historic profile of observed ambient pollutants by visiting http://www.aqistudy.cn/ (last access: 18 October 2018) (China MEP, 2013b).

Supplement. The supplement related to this article is available online at: https://doi.org/10.5194/acp-19-8703-2019-supplement.

Author contributions. GL, as the contact author, provided the ideas and financial support, developed the model code, verified the conclusions, and revised the paper. JW conducted research, designed the experiments, carried out the methodology, performed the simulation, processed the data, prepared the data visualization, and prepared the manuscript with contributions from all authors. NB provided the treatment of meteorological data, analyzed the study data, validated the model performance, and reviewed the manuscript. BH provided the observation data used in the study, synthesized the observation, and reviewed the paper. SL, MZ, QW, ZL, and YW provided the data and the primary data process and reviewed the manuscript. XL, LL, and TF analyzed the initial simulation data, visualized the model results, and reviewed the paper. JC, XT, and JW provided critical reviews pre-publication stage. LTM provided a critical preview and financial support and revised the manuscript.

Competing interests. The authors declare that they have no conflict of interest.

Special issue statement. This article is part of the special issue "Regional transport and transformation of air pollution in eastern China". It is not associated with a conference.

Acknowledgements. This work is financially supported by the National Key R\&D Plan (Quantitative Relationship and Regulation 
Principle between Regional Oxidation Capacity of Atmospheric and Air Quality, 2017YFC0210000) and the National Research Program for Key Issues in Air Pollution Control (DQGG0105). Luisa T. Molina acknowledges support from US NSF award 1560494 .

Financial support. This research has been supported by the National Key R\&D Plan (Quantitative Relationship and Regulation Principle between Regional Oxidation Capacity of Atmospheric and Air Quality) (grant no. 2017YFC0210000) and the U.S. National Science Foundation (grant no. 1560494).

Review statement. This paper was edited by Renyi Zhang and reviewed by two anonymous referees.

\section{References}

Ackerman, T. P.: Model of effect of aerosols on urban climates with particular applications to Los-Angeles basin, J. Atmos. Sci., 34, 531-547, https://doi.org/10.1175/15200469(1977)034<0531:amoteo>2.0.co;2, 1977.

Binkowski, F. S. and Roselle S. J.: Models-3 Community Multiscale Air Quality (CMAQ) model aerosol component: 1. Model description, J. Geophys. Res., 108, 4183, https://doi.org/10.1029/2001JD001409, 2003.

Boucher, O., Randall, D., Artaxo, P., Bretherton, C., Feingold, G., Forster, P., Kerminen, V. M., Kondo, Y., Liao, H., Lohmann, U., Rasch, P., Satheesh, S. K., Sherwood, S., Stevens, B., and Zhang, X. Y.: Clouds and aerosols, in: Climate Change 2013: The Physical Science Basis. Contribution of Working Group I to the Fifth Assessment Report of the Intergovernmental Panel on Climate Change, Cambridge University Press, Cambridge, UK and New York, NY, USA, 2013.

Chand, D., Wood, R., Ghan, S. J., Wang, M. H., Ovchinnikov, M., Rasch, P. J., Miller, S., Schichtel, B., and Moore, T.: Aerosol optical depth increase in partly cloudy conditions, J. Geophys. Res.Atmos., 117, D17207, https://doi.org/10.1029/2012jd017894, 2012

Chen, F. and Dudhia, J.: Coupling an advanced land surfacehydrology model with the Penn State-NCAR MM5 modeling system. Part I: Model implementation and sensitivity, Mon. Weather Rev., 129, 569-585, 2001.

Chou, M.-D. and Suarez, M. J.: A solar radiation parameterization for atmospheric studies, NASA Tech. Rep. NASA/TM-199910460, Vol. 15, 38 pp., 1999.

Chou, M.-D. and Suarez, M. J.: A thermal infrared radiation parameterization for atmospheric studies, NASA/TM-2001-104606, Vol. 19, 55 pp., 2001.

d'Almeida, G. A., Koepke, P., and Shettle, E. P.: Atmospheric aerosols: global climatology and radiative Characteristics, 261 pp., A. Deepak, Hampton, Va., 1991.

Ding, A. J., Fu, C. B., Yang, X. Q., Sun, J. N., Petäjä, T., Kerminen, V.-M., Wang, T., Xie, Y., Herrmann, E., Zheng, L. F., Nie, W., Liu, Q., Wei, X. L., and Kulmala, M.: Intense atmospheric pollution modifies weather: a case of mixed biomass burning with fossil fuel combustion pollution in eastern China, Atmos. Chem.
Phys., 13, 10545-10554, https://doi.org/10.5194/acp-13-105452013, 2013.

Ding, A. J., Huang, X., Nie, W., Sun, J. N., Kerminen, V. M., Petäjä, T., Su, H., Cheng, Y. F., Yang, X. Q., and Wang, M. H.: Enhanced haze pollution by black carbon in megacities in China, Geophys. Res. Lett., 43, 2873-2879, https://doi.org/10.1002/2016GL067745, 2016.

Ding, Y. H., Wu, P., Liu, Y. J., and Song, Y. F.: Environmental and Dynamic Conditions for the Occurrence of Persistent Haze Events in North China, Engineering, 3, 266-271, https://doi.org/10.1016/j.eng.2017.01.009, 2017.

Engstrom, A. and Ekman, A. M. L.: Impact of meteorological factors on the correlation between aerosol optical depth and cloud fraction, Geophys. Res. Lett., 37, L18814, https://doi.org/10.1029/2010g1044361, 2010.

Fast, J. D., Gustafson, W. I., Easter, R. C., Zaveri, R. A., Barnard, J. C., Chapman, E. G., Grell, G., and Peckham, S. E.: Evolution of Ozone, Particulates, and Aerosol Direct Radiative Forcing in the Vicinity of Houston Using a Fully Coupled Meteorology-Chemistry-Aerosol Model, J. Geophys. Res.Atmos., 111, D21305, https://doi.org/10.1029/2005jd006721, 2006.

Feng, T., Bei, N., Huang, R.-J., Cao, J., Zhang, Q., Zhou, W., Tie, X., Liu, S., Zhang, T., Su, X., Lei, W., Molina, L. T., and $\mathrm{Li}, \mathrm{G}$. : Summertime ozone formation in Xi' an and surrounding areas, China, Atmos. Chem. Phys., 16, 4323-4342, https://doi.org/10.5194/acp-16-4323-2016, 2016.

Forkel, R., Werhahn, J., Hansen, A.B., Mckeen, S., Peckham, S., Grell, G., Suppan, P.: Effect of aerosol-radiation feedback on regional air quality - A case study with WRF/Chem, Atmos. Environ., 53, 202-211, 2012.

Fountoukis, C., Nenes, A., Sullivan, A., Weber, R., Van Reken, T., Fischer, M., Matías, E., Moya, M., Farmer, D., and Cohen, R. C.: Thermodynamic characterization of Mexico City aerosol during MILAGRO 2006, Atmos. Chem. Phys., 9, 2141-2156, https://doi.org/10.5194/acp-9-2141-2009, 2009.

Fu, J. S., Hsu, N. C., Gao, Y., Huang, K., Li, C., Lin, N.-H., and Tsay, S.-C.: Evaluating the influences of biomass burning during 2006 BASE-ASIA: a regional chemical transport modeling, Atmos. Chem. Phys., 12, 3837-3855, https://doi.org/10.5194/acp12-3837-2012, 2012.

Gao, M., Carmichael, G. R., Wang, Y., Saide, P. E., Yu, M., Xin, J., Liu, Z., and Wang, Z.: Modeling study of the 2010 regional haze event in the North China Plain, Atmos. Chem. Phys., 16, 1673-1691, https://doi.org/10.5194/acp-16-1673-2016, 2016.

Gao, Y., Zhang, M., Liu, Z., Wang, L., Wang, P., Xia, X., Tao, M., and Zhu, L.: Modeling the feedback between aerosol and meteorological variables in the atmospheric boundary layer during a severe fog-haze event over the North China Plain, Atmos. Chem. Phys., 15, 4279-4295, https://doi.org/10.5194/acp15-4279-2015, 2015.

Guo, S., Hu, M., Zamora, M. L., Peng, J. F., Shang, D. J., Zheng, J., Du, Z. F., Wu, Z., Shao, M., Zeng, L. M., Molina, M. J., and Zhang, R. Y.: Elucidating severe urban haze formation in China, P. Natl. Acad. Sci. USA., 111, 17373-17378, https://doi.org/10.1073/pnas.1419604111, 2014.

Grandey, B. S., Stier, P., and Wagner, T. M.: Investigating relationships between aerosol optical depth and cloud fraction using satellite, aerosol reanalysis and general circu- 
lation model data, Atmos. Chem. Phys., 13, 3177-3184, https://doi.org/10.5194/acp-13-3177-2013, 2013.

Grell, G. A. and Devenyi, D.: A generalized approach to parameterizing convection combining ensemble and data assimilation techniques, Geophys. Res. Lett., 29, 38-1-38-4, https://doi.org/10.1029/2002GL015311, 2002.

Grell, G. A., Peckham, S. E., Schmitz, R., McKeen, S. A., Frost, G., Skamarock, W. C., and Eder, B.: Fully coupled "online" chemistry within the WRF model, Atmos. Environ., 39, 6957-6975, https://doi.org/10.1016/j.atmosenv.2005.04.027, 2005.

Grell, G., Freitas, S. R., Stuefer, M., and Fast, J.: Inclusion of biomass burning in WRF-Chem: impact of wildfires on weather forecasts, Atmos. Chem. Phys., 11, 5289-5303, https://doi.org/10.5194/acp-11-5289-2011, 2011.

Guenther, A., Karl, T., Harley, P., Wiedinmyer, C., Palmer, P. I., and Geron, C.: Estimates of global terrestrial isoprene emissions using MEGAN (Model of Emissions of Gases and Aerosols from Nature), Atmos. Chem. Phys., 6, 3181-3210, https://doi.org/10.5194/acp-6-3181-2006, 2006.

Hong, S.-Y. and Lim, J.-O. J.: The WRF Single-Moment 6-Class Microphysics Scheme (WSM6), Asia-Pac. J. Atmos. Sci., 42, 129-151, 2006

Horowitz, L. W., Walters, S., Mauzerall, D. L., Emmons, L. K., Rasch, P. J., Granier, C., Tie, X. X., Lamarque, J. F., Schultz, M. G., Tyndall, G. S., Orlando, J. J., and Brasseur, G. P.: A global simulation of tropospheric ozone and related tracers: Description and evaluation of MOZART, version 2, J. Geophys. Res.-Atmos., 108, 4784, https://doi.org/10.1029/2002jd002853, 2003.

IPCC (Intergovernmental Panel on Climate Change): The Physical Science Basis of Climate Change: Changes in Atmospheric Constituents and in Radiative Forcing, Cambridge University Press, New York, 26-27, 2007.

Jacobson, M. Z.: Studying the effects of aerosols on vertical photolysis rate coefficient and temperature profiles over an urban airshed, J. Geophys. Res.-Atmos., 103, 10593-10604, https://doi.org/10.1029/98jd00287, 1998.

Jacobson, M. Z.: Analysis of aerosol interactions with numerical techniques for solving coagulation, nucleation, condensation, dissolution, and reversible chemistry among multiple size distributions, J. Geophys. Res.-Atmos., 107, AAC 2-1-AAC 2-23, https://doi.org/10.1029/2001jd002044, 2002.

Janjić, Z. I.: Nonsingular Implementation of the Mellor-Yamada Level 2.5 Scheme in the NCEP Meso Model, Ncep Office Note, 436, 2002.

Kawamoto, K., Hayasaka, T., Uno, I., and Ohara, T.: A correlative study on the relationship between modeled anthropogenic aerosol concentration and satellite-observed cloud properties over east Asia, J. Geophys. Res.-Atmos., 111, D19201, https://doi.org/10.1029/2005jd006919, 2006.

Koch, D. and Del Genio, A. D.: Black carbon semi-direct effects on cloud cover: review and synthesis, Atmos. Chem. Phys., 10, 7685-7696, https://doi.org/10.5194/acp-10-7685-2010, 2010.

Li, G., Zhang, R., Fan, J., and Tie, X.: Impacts of black carbon aerosol on photolysis and ozone, J. Geophys. Res., 110, D23206, https://doi.org/10.1029/2005jd005898, 2005

Li, G., Wang, Y., and Zhang, R.: Implementation of a twomoment bulk microphysics scheme to the WRF model to investigate aerosol-cloud interaction, J. Geophys. Res., 113, D15211, https://doi.org/10.1029/2007JD009361, 2008a.
Li, G., Wang, Y., Lee, K.-H., Diao, Y., and, Zhang, R.: Increased winter precipitation over the North Pacific from 1984-1994 to 1995-2005 inferred from the Global Precipitation Climatology Project, Geophys. Res. Lett., 35, L13821, https://doi.org/10.1029/2008GL034668, 2008b.

Li, G., Wang, Y., Lee, K.-H., Diao, Y., and Zhang, R.: Impacts of aerosols on the development and precipitation of a mesoscale squall line, J. Geophys. Res., 114, D17205, https://doi.org/10.1029/2008JD011581, 2009.

Li, G., Lei, W., Zavala, M., Volkamer, R., Dusanter, S., Stevens, P., and Molina, L. T.: Impacts of HONO sources on the photochemistry in Mexico City during the MCMA2006/MILAGO Campaign, Atmos. Chem. Phys., 10, 6551-6567, https://doi.org/10.5194/acp-10-6551-2010, 2010.

Li, G., Bei, N., Tie, X., and Molina, L. T.: Aerosol effects on the photochemistry in Mexico City during MCMA2006/MILAGRO campaign, Atmos. Chem. Phys., 11, 51695182, https://doi.org/10.5194/acp-11-5169-2011, 2011a.

Li, G., Zavala, M., Lei, W., Tsimpidi, A. P., Karydis, V. A., Pandis, S. N., Canagaratna, M. R., and Molina, L. T.: Simulations of organic aerosol concentrations in Mexico City using the WRF-CHEM model during the MCMA2006/MILAGRO campaign, Atmos. Chem. Phys., 11, 37893809, https://doi.org/10.5194/acp-11-3789-2011, 2011 b.

Li, G., Lei, W., Bei, N., and Molina, L. T.: Contribution of garbage burning to chloride and $\mathrm{PM}_{2.5}$ in Mexico City, Atmos. Chem. Phys., 12, 8751-8761, https://doi.org/10.5194/acp12-8751-2012, 2012.

Li, G., Bei, N., Cao, J., Huang, R., Wu, J., Feng, T., Wang, Y., Liu, S., Zhang, Q., Tie, X., and Molina, L. T.: A possible pathway for rapid growth of sulfate during haze days in China, Atmos. Chem. Phys., 17, 3301-3316, https://doi.org/10.5194/acp17-3301-2017, 2017a.

Li, G., Bei, N., Cao, J., Wu, J., Long, X., Feng, T., Dai, W., Liu, S., Zhang, Q., and Tie, X.: Widespread and persistent ozone pollution in eastern China during the non-winter season of 2015: observations and source attributions, Atmos. Chem. Phys., 17, 2759-2774, https://doi.org/10.5194/acp-17-2759-2017, 2017b.

Liao, X., Sun, Z., Tang, Y., Pu, W., Li, Z., and Lu, B.: Meteorological mechanism for the formation of a serious pollution case in Beijing in the background of northerly flow at upper levels, Environm. Sci., 36, 801-808, 2015 (in Chinese).

Liggio, J., Li, S. M., and McLaren, R.: Reactive uptake of glyoxal by particulate matter, J. Geophys. Res.-Atmos., 110, D10304, https://doi.org/10.1029/2004jd005113, 2005.

Liu, H., Hu, B., Zhang, L., Wang, Y. S., and Tian, P. F.: Spatiotemporal characteristics of ultraviolet radiation in recent 54 years from measurements and reconstructions over the Tibetan Plateau, J. Geophys. Res.-Atmos., 121, 7673-7690, https://doi.org/10.1002/2015jd024378, 2016.

Liu, Q., Jia, X. C., Quan, J. N., Li, J. Y., Li, X., Wu, Y. X., Chen, D., Wang, Z. F., and Liu, Y. G.: New positive feedback mechanism between boundary layer meteorology and secondary aerosol formation during severe haze events, Sci. Rep.-UK, 8, 6095, https://doi.org/10.1038/s41598-018-24366-3, 2018.

Ministry of Environmental Protection, China (China MEP): Air Quality Observation Real-time Release Platform of MEP Data Center, available at: http://106.37.208.233:20035/ (last access: 18 October 2018), 2013a. 
Ministry of Environmental Protection, China (China MEP): Online Monitoring and Analysis Platform of China Air Quality, available at: http://www.aqistudy.cn/ (last access: 18 October 2018), 2013 b.

Nakajima, T., Higurashi, A., Kawamoto, K., and Penner, J. E.: A possible correlation between satellite-derived cloud and aerosol microphysical parameters, Geophys. Res. Lett., 28, 1171-1174, https://doi.org/10.1029/2000g1012186, 2001.

Nenes, A., Pandis, S. N., and Pilinis, C.: ISORROPIA: A new thermodynamic equilibrium model for multiphase multicomponent inorganic aerosols, Aquat. Geochem., 4, 123-152, https://doi.org/10.1023/a:1009604003981, 1998.

Penner, J. E., Xu, L., Liousse, C., Assamoi, E., Flanner, M. G., Edwards, R., and McConnell, J.: Atmospheric absorption: Can observations constrain the direct and indirect effect of organic and BC aerosols on climate, American Geophysical Union, AGU Fall Meeting Abstract, 2010.

Perez, C., Nickovic, S., Pejanovic, G., Baldasano, J. M., and Ozsoy, E.: Interactive dust-radiation modeling: A step to improve weather forecasts, J. Geophys. Res.-Atmos., 111, D16206, https://doi.org/10.1029/2005jd006717, 2006.

Petäjä, T., Järvi, L., Kerminen, V. M., Ding, A. J., Sun, J. N., Nie, W., Kujansuu, J., Virkkula, A., Yang, X., and Fu, C. B.: Enhanced air pollution via aerosol-boundary layer feedback in China, Sci. Rep.-UK, 6, 18998, https://doi.org/10.1038/srep18998, 2016.

Pui, D. Y. H., Chen, S. C., and Zuo, Z. L.: $\mathrm{PM}_{2.5}$ in China: Measurements, sources, visibility and health effects, and mitigation, Particuology, 13, 1-26, https://doi.org/10.1016/j.partic.2013.11.001, 2014.

Quan, J., Gao, Y., Zhang, Q., Tie, X., Cao, J., Han, S., Meng, J., Chen, P., and Zhao, D.: Evolution of planetary boundary layer under different weather conditions, and its impact on aerosol concentrations, Particuology, 11, 34-40, https://doi.org/10.1016/j.partic.2012.04.005, 2013.

Robinson, A. L., Donahue, N. M., Shrivastava, M. K., Weitkamp, E. A., Sage, A. M., Grieshop, A. P., Lane, T. E., Pandis, S. N., and Pierce, J. R.: Rethinking organic aerosols: semivolatile emissions and photochemical aging, Science, 315, 1259-1262, 2007.

Santese, M., Perrone, M. R., Zakey, A. S., De Tomasi, F., and Giorgi, F.: Modeling of Saharan dust outbreaks over the Mediterranean by RegCM3: case studies, Atmos. Chem. Phys., 10, 133156, https://doi.org/10.5194/acp-10-133-2010, 2010.

Satheesh, S. K., Vinoj, V., and Krishnamoorthy, K.: Assessment of Aerosol Radiative Impact over Oceanic Regions Adjacent to Indian Subcontinent Using Multisatellite Analysis, Adv. Meteorol., 13, 139186, https://doi.org/10.1155/2010/139186, 2010.

Shrivastava, M. K., Lane, T. E., Donahue, N. M., Pandis, S. N., and Robinson, A. L.: Effects of gas particle partitioning and aging of primary emissions on urban and regional organic aerosol concentrations, J. Geophys. Res.-Atmos., 113, D18301, https://doi.org/10.1029/2007jd009735, 2008.

Sivaraman, C., McFarlane, S., and Chapman E.: Planetary boundary layer (PBL) height value added product (VAP): Radiosonde retrievals [J/OL], U.S. DOE, Office of Science, Office of Biological and Environment Research, DOE/SC-ARM/TR-132, available at: http://www.doc88.com/p-9032320085477.html (last access: 25 October 2018), 2013.

Taylor, K.: Summarizing multiple aspects of model performance in single diagram, J. Geophys. Res., 106, 7183-7192, 2001.
Tie, X., Huang, R. J., Cao, J., Zhang, Q., Cheng, Y., Su, H., Chang, D., Pöschl, U., Hoffmann, T., and Dusek, U.: Severe Pollution in China Amplified by Atmospheric Moisture, Sci. Rep.-UK, 7, 15760, https://doi.org/10.1038/s41598-017-15909-1, 2017.

Vogel, B., Vogel, H., Bäumer, D., Bangert, M., Lundgren, K., Rinke, R., and Stanelle, T.: The comprehensive model system COSMOART - Radiative impact of aerosol on the state of the atmosphere on the regional scale, Atmos. Chem. Phys., 9, 8661-8680, https://doi.org/10.5194/acp-9-8661-2009, 2009.

Volkamer, R., Martini, F. S., Molina, L. T., Salcedo, D., Jimenez, J. L., and Molina, M. J.: A missing sink for gas-phase glyoxal in Mexico City: Formation of secondary organic aerosol, Geophys. Res. Lett., 34, L19807, https://doi.org/10.1029/2007g1030752, 2007.

Wang, H., Shi, G. Y., Zhang, X. Y., Gong, S. L., Tan, S. C., Chen, B., Che, H. Z., and Li, T.: Mesoscale modelling study of the interactions between aerosols and PBL meteorology during a haze episode in China Jing-Jin-Ji and its near surrounding region - Part 2: Aerosols' radiative feedback effects, Atmos. Chem. Phys., 15, 3277-3287, https://doi.org/10.5194/acp15-3277-2015, 2015.

Wang, J., Wang, S., Jiang, J., Ding, A., Zheng, M., Zhao, B., Wong, D. C., Zhou, W., Zheng, G., and Wang, L.: Impact of aerosol-meteorology interactions on fine particle pollution during China's severe haze episode in January 2013, Environ. Res. Lett., 9, 094002, https://doi.org/10.1088/1748-9326/9/9/094002, 2014.

Wang, Y., Wan, Q., Meng, W., Liao, F., Tan, H., and Zhang, R.: Long-term impacts of aerosols on precipitation and lightning over the Pearl River Delta megacity area in China, Atmos. Chem. Phys., 11, 12421-12436, https://doi.org/10.5194/acp-11-124212011, 2011.

Wang, Z. F., Li, J., Wang, Z., Yang, W. Y., Tang, X., Ge, B. Z., Yan, P. Z., Zhu, L. L., Chen, X. S., Chen, H. S., Wand, W., Li, J. J., Liu, B., Wang, X. Y., Wand, W., Zhao, Y. L., Lu, N., and $\mathrm{Su}, \mathrm{D}$. B.: Modeling study of regional severe hazes over mid-eastern China in January 2013 and its implications on pollution prevention and control, Sci. China Earth Sci., 57, 3-13, https://doi.org/10.1007/s11430-013-4793-0, 2014.

Wesely, M. L.: Parameterization of surface resistances to gaseous dry deposition in regional-scale numerical models, Atmos. Environ., 23, 1293-1304, https://doi.org/10.1016/00046981(89)90153-4, 1989.

Wong, D. C., Pleim, J., Mathur, R., Binkowski, F., Otte, T., Gilliam, R., Pouliot, G., Xiu, A., Young, J. O., and Kang, D.: WRFCMAQ two-way coupled system with aerosol feedback: software development and preliminary results, Geosci. Model Dev., 5, 299-312, https://doi.org/10.5194/gmd-5-299-2012, 2012.

Wu, P., Ding, Y. H., and Liu, Y. J.: Atmospheric circulation and dynamic mechanism for persistent haze events in the Beijing-Tianjin-Hebei region, Adv. Atmos. Sci., 34, 429-440, https://doi.org/10.1007/s00376-016-6158-z, 2017.

Yang, X., Zhao, C., Guo, J., and Wang, Y.: Intensification of aerosol pollution associated with its feedback with surface solar radiation and winds in Beijing, J. Geophys. Res.-Atmos., 121, 4093-4099, 2016.

Zhang, B., Wang, Y., and Hao, J.: Simulating aerosol-radiationcloud feedbacks on meteorology and air quality over eastern China under severe haze conditionsin winter, Atmos. 
Chem. Phys., 15, 2387-2404, https://doi.org/10.5194/acp-152387-2015, 2015.

Zhang, D. F., Zakey, A. S., Gao, X. J., Giorgi, F., and Solmon, F.: Simulation of dust aerosol and its regional feedbacks over East Asia using a regional climate model, Atmos. Chem. Phys., 9, 1095-1110, https://doi.org/10.5194/acp-9-1095-2009, 2009.

Zhang, Q., Streets, D. G., Carmichael, G. R., He, K. B., Huo, H., Kannari, A., Klimont, Z., Park, I. S., Reddy, S., Fu, J. S., Chen, D., Duan, L., Lei, Y., Wang, L. T., and Yao, Z. L.: Asian emissions in 2006 for the NASA INTEX-B mission, Atmos. Chem. Phys., 9, 5131-5153, https://doi.org/10.5194/acp-9-5131-2009, 2009.

Zhang, R., Suh, I., Zhao, J., Zhang, D., Fortner, E. C., Tie, X., Molina, L. T., and Molina, M. J.: Atmospheric new particle formation enhanced by organic acids, Science, 304, 1487-1490, 2004.

Zhang, R., Jing, J., Tao, J., Hsu, S.-C., Wang, G., Cao, J., Lee, C. S. L., Zhu, L., Chen, Z., Zhao, Y., and Shen, Z.: Chemical characterization and source apportionment of $\mathrm{PM}_{2.5}$ in Beijing: seasonal perspective, Atmos. Chem. Phys., 13, 7053-7074, https://doi.org/10.5194/acp-13-7053-2013, 2013.

Zhang, R. Y., Li, G. H., Fan, J. W., Wu, D. L., and Molina, M. J.: Intensification of Pacific storm track linked to Asian pollution, P. Natl. Acad. Sci. USA, 104, 5295-5299, https://doi.org/10.1073/pnas.0700618104, 2007.

Zhang, X., Zhang, Q., Hong, C. P., Zheng, Y. X., Geng, G. N., Tong, D., Zhang, Y. X., and Zhang, X. Y.: Enhancement of $\mathrm{PM}_{2.5}$ Concentrations by Aerosol-Meteorology Interactions Over China, J. Geophys. Res.-Atmos., 123, 1179-1194, https://doi.org/10.1002/2017jd027524, 2018a.
Zhang, X., Zhong, J., Wang, J., Wang, Y., and Liu, Y.: The interdecadal worsening of weather conditions affecting aerosol pollution in the Beijing area in relation to climate warming, Atmos. Chem. Phys., 18, 5991-5999, https://doi.org/10.5194/acp18-5991-2018, 2018b.

Zhang, Y., Wen, X. Y., and Jang, C. J.: Simulating chemistryaerosol-cloud-radiation-climate feedbacks over the continental U.S. using the online-coupled weather research forecasting model with chemistry (WRF/Chem), Atmos. Environ., 44, 35683582, 2010.

Zhao, C. S., Ishizaka, Y., and Peng, D. Y.: Numerical study on impacts of multi-component aerosols on marine cloud microphysical properties, J. Meteorol. Soc. Jpn., 83, 977-986, https://doi.org/10.2151/jmsj.83.977, 2005

Zhao, J., Levitt, N. P., Zhang, R., and Chen, J.: Heterogeneous reactions of methylglyoxal in acidic media: implications for secondary organic aerosol formation, Environ. Sci. Technol., 40, 7682-7687, 2006

Zhong, J., Zhang, X., Dong, Y., Wang, Y., Liu, C., Wang, J., Zhang, Y., and Che, H.: Feedback effects of boundary-layer meteorological factors on cumulative explosive growth of $\mathrm{PM}_{2.5}$ during winter heavy pollution episodes in Beijing from 2013 to 2016 , Atmos. Chem. Phys., 18, 247-258, https://doi.org/10.5194/acp18-247-2018, 2018 